\title{
Soil nitrogen storage and availability to crops are increased by conservation agriculture practices in rice-based cropping systems in the Eastern Gangetic Plains
}

\author{
Md. Khairul Alam ${ }^{\mathrm{a}, \mathrm{b}, *}$, Richard W. Bell ${ }^{\mathrm{a}}$, M.E. Haque ${ }^{\mathrm{a}}$, M.A. Islam ${ }^{\mathrm{c}}$, M.A. Kader ${ }^{\mathrm{a}, \mathrm{d}, \mathrm{e}}$ \\ ${ }^{a}$ Agriculture Discipline, College of Science, Health, Education and Engineering, Murdoch University, Western Australia, Australia \\ ${ }^{\mathrm{b}}$ Soil Science Division, Bangladesh Agricultural Research Institute, Bangladesh \\ ${ }^{\mathrm{c}}$ Pulse Research Centre, Bangladesh Agricultural Research Institute, Ishurdi, Bangladesh \\ ${ }^{\mathrm{d}}$ Department of Soil Science, Bangladesh Agricultural University, Mymensingh, 2202, Bangladesh \\ ${ }^{\mathrm{e}}$ School of Agriculture and Food Technology, University of South Pacific, Samoa
}

\section{A R T I C L E I N F O}

\section{Keywords:}

Available N

$\mathrm{N}$ sequestration

Paddy-upland rotation

Recycled N

Rice-based-triple cropping system

\begin{abstract}
A B S T R A C T
On-farm adoption of minimum soil disturbance and increased residue retention will alter nitrogen (N) dynamics in soils and $\mathrm{N}$ fertiliser management in the intensive rice-based triple cropping systems of the Eastern Gangetic Plains. However, the consequences of changes in $\mathrm{N}$ forms, $\mathrm{N}$ mineralisation and its availability for crops have not been determined. Field experiments were conducted at two locations (Alipur and Digram) of north-west Bangladesh (NWB) to examine N cycling under three planting practices (conventional tillage (CT), strip planting (SP) and bed planting (BP)) with increased (HR) or low residue retention (LR- the current practice) on Calcareous Brown Flood Plain and Grey Terrace soils. Total N and available N were measured on soil samples as was $\mathrm{N}$ uptake by crops at different growth stages in the 13-14th (Alipur) and 12-13th (Digram) crops since treatments commenced. At each location (0-10 cm soil depth), SP, including non-puddled transplanting of rice seedlings (NP), together with HR increased total $\mathrm{N}$ by 9 and $32 \%$ relative to BPHR, and CTHR and by $62 \%$ relative to the current farm practice (CTLR). In general, the cumulative available $\mathrm{N}$ in soils during mustard and rice cropping under CT with HR was higher than other crop establishment and residue retention practices while under wheat and jute, total availability of $\mathrm{N}$ did not vary among crop establishment types with increased residue retention. Nitrogen availability in the initial phase of crop growth (0-60 DAS) was generally higher with CT than SP and BP. By contrast, for all crops, the estimated potentially mineralisable $\mathrm{N}$ was higher and its decay rate was lower under SPHR than other crop establishment and residue retention practices. Conservation Agriculture practices (SP, and NP of rice, together with HR) have altered the $\mathrm{N}$ cycling by reducing the level of mineral $\mathrm{N}$ available to plants in the early growing season when crop demand is low, but by increasing soil total $\mathrm{N}$ $(0-10 \mathrm{~cm})$ and plant $\mathrm{N}$ uptake which enhanced the synchrony between crop demand and available $\mathrm{N}$ supply.
\end{abstract}

\section{Introduction}

Adoption of Conservation Agriculture (CA) by growers in the intensive rice-based triple cropping systems in the EGP is increasing (Singh et al., 2011; Taneja et al., 2014; Haque et al., 2016). Minimum soil disturbance methods of planting, such as zero tillage or strip planting, have been developed for upland crops in the rice growing regions of the Indo-Gangetic Plains (Gathala et al., 2015; Bell et al., 2019). However, the benefits of CA practices in upland cropping for soil properties are destroyed during wetland cropping following tillage and puddling. Non-puddled transplanting of rice, a novel crop establishment practice designed for CA cropping systems (Alam et al., 2016a; Haque et al., 2016), along with zero tillage or strip planting are CA-compatible practices for rice. However, there is limited understanding of cycling of $\mathrm{N}$ in soils under the CA practices in intensive rice-based triple cropping systems which involve the rotation of winter dryland and summer wetland rice crops.

An improved knowledge about the dynamics of residue nitrogen $(\mathrm{N})$ turnover and the availability of both soil native $\mathrm{N}$ and fertiliser $\mathrm{N}$ is required to quantify the effects of minimum soil disturbance and increased crop residue retention on soil quality, crop production and $\mathrm{N}$ fertilizer management. As native soil $\mathrm{N}$ mineralisation provides $20-80$

\footnotetext{
* Correspondence author.

E-mail address: khairul.krishi@gmail.com (Md. K. Alam).
} 
$\%$ of the $\mathrm{N}$ used by plants (Broadbent, 1984), the level of crop residues and its management in CA have crucial effects on crop N supply (Kumar and Goh, 2003). Native soil $\mathrm{N}$ mineralisation determines the amount of $\mathrm{N}$ fertiliser required to optimize crop yield and profit (Kader et al., 2013).

The suitability of crop residues as a source of $\mathrm{N}$ depends on the rate of net mineralisation of $\mathrm{N}$ in relation to the demand of the growing crop (Watkins and Barraclough, 1996). The $\mathrm{N}$ mineralisation of $\mathrm{N}$ in residues is also strongly regulated by their quality and placement (Jin et al., 2008). While conventional tillage practices incorporate residues into the soil, crop shoot residues remain standing or above the soil surface in minimum tillage (Curtin et al., 2008) where they are less accessible to microbial breakdown (Verhulst et al., 2013). The quality and amounts of residues added to the soil are determined by the crop species in the rotation (Wienhold and Halvorson, 1999; Alam et al., 2016b, 2018). Crop rotation (Baldock, 2007), residue retention (Franzluebbers et al., 1994) and tillage (Zhou et al., 2014) alter N dynamics, and are important factors for sequestering $\mathrm{N}$ in soil (Balota et al., 2004). The retention of more residues in the intensive triple-cropping systems of the EGP will alter the dynamics of $\mathrm{N}$ in soil but nature of these changes for soil $\mathrm{N}$ forms and availability to crops is poorly understood.

Under continuous rice double- or triple-cropping, soils can accumulate significant amounts of $\mathrm{N}$ over time, even with the removal of all aboveground biomass from the field and without organic manure application (Cassman et al., 1995). This can be attributed to the short fallow period that results in incomplete re-oxidation of soils and the return of significant amounts of crop residues particularly roots more than once per year (Kirk and Olk, 2000). In contrast, accumulated N declines in most rice-upland crop systems such as rice-wheat (Witt et al., 2000). Kirk and Olk (2000) and Liping and Erda (2001) found under anaerobic (submerged) conditions that both decomposition of organic residues and mineralisation rates of residues and native SOM are considerably retarded in comparison with those under aerobic (upland) conditions. By contrast, Huang et al. (1998) and Kader et al. (2013) reported stronger $\mathrm{N}$ availability of paddy soils under submerged conditions than under non-submerged conditions, which could be due to the higher metabolic utilisation of SOM under anaerobic condition and release of some mineral-bound $\mathrm{N}$ resulting from Fe reduction. Zhou et al. (2014) reviewed $\mathrm{N}$ cycling in paddy-upland crop rotations and found the rotation caused soil $\mathrm{N}$ depletion due to over use of irrigation water, excessive disturbance of soil, removal of residues from field or burning. In 2014, cropping intensity of rice-based systems in Bangladesh was $191 \%$ (Mondal et al., 2015). The cropping intensity of ricebased intensive cropping system is around $200 \%$ ranging from 128 to $267 \%$ (Nasim et al., 2017). In the EGP ecosystem where rice is the dominant crop of paddy-upland rotations and there are short fallow periods and periodic drying-wetting of soils, there is limited understanding of the dynamics of soil $\mathrm{N}$ storage and release (Wang and Hsieh, 2002). Drying and re-wetting of soils either by seasonal changes or by midseason drying control decomposition of retained residues and consequently modify $\mathrm{N}$ dynamics in rice-based intensive cropping systems (Kirk and Olk, 2000). During drying and rewetting of soils, microbial activity increases, resulting in increased SOM decomposition (Orchard and Cook, 1983) and $\mathrm{N}$ release. However, under the decreased soil disturbance and increased residue retention with CA practices in intensive rice-based cropping systems, the $\mathrm{N}$ dynamics and cycling may well differ (Smith et al., 2001; Sisti et al., 2004). For the intensive rice-based cropping systems, there are also knowledge gaps in relation to the crop-to-crop dynamics of $\mathrm{N}$ cycling in soils and their implications for soil $\mathrm{N}$ sequestration.

Reliable prediction of $\mathrm{N}$ release from residues and SOM in upland-wetland soil management will help to establish the rates of $\mathrm{N}$ fertiliser application for optimum and economic crop yield. Few studies using $\mathrm{N}$ mineralisation models have been conducted for upland or wetland crops in the EGP under CA practices. This study involved a recently developed non-puddled transplanting of rice into rice- based triple cropping systems together with increased residue retention to determine how they perform in terms of $\mathrm{N}$ dynamics in soils (Alam et al., 2016a; Haque et al., 2016). The main objective of this study was, therefore, to determine the effect of crop establishment by minimal soil disturbance and increased residue retention on $\mathrm{N}$ forms and $\mathrm{N}$ availability in soils under CA practices for $\mathrm{N}$ uptake by rice, jute, mustard and wheat crops in rice-upland triple-crop rotations.

\section{Materials and methods}

\subsection{Climates of the experimental sites and irrigation details}

Maximum temperatures at Alipur and Digram ranged between $15-38^{\circ} \mathrm{C}$ and $17-39^{\circ} \mathrm{C}$, respectively, while the minimum temperatures were 9.5 and $10^{\circ} \mathrm{C}$, respectively. April was the warmest and January the coldest month at both sites/locations. The annual precipitation of the study area was $1370 \pm 323 \mathrm{~mm}$. November, December and January were almost devoid of rain. Rainfall was below average in February, March and April of 2015, whereas May and June experienced above average rainfall at both sites and the second quarter of April and May received most concentrated rainfall (Alam et al., 2018).

The mustard crop at Alipur was irrigated twice, irrigated (boro) rice 10 times, while wheat in Digram was irrigated thrice and jute only once. The early monsoon period (April- June) experienced higher amount of rains than winter.

\subsection{Study site and experimental design}

Nitrogen dynamics was studied on long-term experiments in NWB at two locations (Alipur village, Durgapur upazila, Rajshahi division in the Agro-ecological Zone known as the Level Barind Tract (LBT) and Digram village, Godagari upazilla, Rajshahi division in the Agro-ecological Zone known as the High Barind Tract (HBT)) (SRDI, 2005). The LBT soil belongs to silty loam texture class (24\% sand, $53 \%$ silt and $23 \%$ clay). On the other hand, the HBT has silty clay loam texture class (26\% sand, $46 \%$ silt and $29 \%$ clay). Mica, kaolinite, interstratified mica-vermiculite-smectite and kaolinite-smectite are the predominant clay minerals found in these soil types (Moslehuddin et al., 1999). The soils were slightly acidic and classed as Calcareous Brown Flood Plain (Aeric Eutrochrept) at Alipur and Grey Terrace soils (Aeric Albaquept) at Digram. The field site at Alipur was moderately drainable and the Digram was highly drainable.

Three crop establishment practices (CT, SP/NP and BP/NP) and two residue retention levels (high residue retention - HR and low residue retention - LR) were examined in the field in 2014. The experiments were established in 2010 with four replicates of all treatments (Table 1) (Islam, 2016). The experimental design, followed for the previous 14 crops (three crops per year since 2010) at Alipur and 12 crops in Digram used a split-plot layout where soil disturbance practices were assigned to the main plots and residue retention levels to the subplots. Low residue retention (LR) refers to current farmer practice for the region which involves keeping about $20 \%$ (by height) of the standing rice crop residue in the field after harvest. On the other hand, high residue (HR) retains $\sim 50 \%$ of standing rice residue after harvest. The same residue retention levels were followed for wheat crops at Digram. For the previous lentil (Lens culinaris L.), mungbean (Vigna radiata L.) and mustard (Brassica campestris L.) crops in the rotation at Alipur, and the previous jute (Corchorus olitorius) (excluding the harvested jute sticks) and chickpea crops in Digram, LR involved complete removal while HR returned all crop residues to the plot as mulch after sowing. The cropping sequence followed for the first three years in the field of Alipur was lentil - mungbean - rainfed monsoon (aman) rice, while in Digram, the rotation involved wheat-mungbean-rainfed monsoon rice up to 2012, then it was chickpea-jute-rainfed monsoon rice for 2013-14. In 2014-15 at Alipur, the monsoon rice was followed by mustard and then irrigated dry season (boro) rice. The Digram site in 
Table 2

Nitrogen fertiliser added for each crop $\left(\mathrm{kg} \mathrm{N} \mathrm{ha}^{-1}\right)$. The rates of $\mathrm{N}$ applied for $\mathrm{HR}$ were adjusted according to the content of extra $\mathrm{N}$ added in residue.

\begin{tabular}{|c|c|c|c|c|c|c|}
\hline \multirow{2}{*}{$\begin{array}{l}\text { Crops/ } \\
\text { Treatments }\end{array}$} & \multicolumn{3}{|l|}{ Alipur } & \multicolumn{3}{|l|}{ Digram } \\
\hline & $\begin{array}{l}\text { Monsoon } \\
\text { rice (Aman) }\end{array}$ & Mustard & $\begin{array}{l}\text { Irrigated } \\
\text { rice (Boro) }\end{array}$ & $\begin{array}{l}\text { Monsoon } \\
\text { rice }\end{array}$ & Wheat & Jute \\
\hline CTLR & 74 & 60 & 125 & 90 & 120 & 40 \\
\hline CTHR & 74 & 55 & 115 & 80 & 110 & 35 \\
\hline SPLR & 74 & 60 & 125 & 90 & 120 & 40 \\
\hline SPHR & 74 & 55 & 115 & 80 & 110 & 35 \\
\hline BPLR & 74 & 60 & 125 & 90 & 120 & 40 \\
\hline BPHR & 74 & 55 & 115 & 80 & 110 & 35 \\
\hline
\end{tabular}

2014-15 had also monsoon rice followed by wheat and then jute.

Chemical inputs (pesticides and recommended dose of fertilisers) for all the crops were recorded. The recommended fertiliser application for each of the crops grown at both sites was based on soil testing. Nitrogen as urea was applied for all crops except monsoon rice (aman) as shown in Table 2. Phosphorus, potassium, sulphur and zinc were applied at the rate of $35,65,20$ and $3 \mathrm{~kg} \mathrm{ha}^{-1}$ for mustard; 120, 55, 80, 10 , and $2 \mathrm{~kg} \mathrm{ha}^{-1}$ for irrigated rice; $11,20,20$ and $1 \mathrm{~kg} \mathrm{ha}^{-1}$ for monsoon rice at Alipur site; $10,30,10$ and $1.5 \mathrm{~kg} \mathrm{ha}^{-1}$ for monsoon rice at Digram 35, 75, 20, $2 \mathrm{~kg} \mathrm{ha}^{-1}$ for wheat and 80, 15, 30, 10 and $0.5 \mathrm{~kg} \mathrm{ha}^{-1}$ for jute crops. Before sowing, weeds were suppressed with glyphosate (as Roundup @1 L ha ${ }^{-1}$ ) in all SP and BP plots and in CT plots by tillage and wet puddling of soil. For post-emergence weed control, herbicide Sunrise 150WG@100 g ha ${ }^{-1}$ (Ethoxysulfuron 15\% WDG) was used for rice. Wheat, lentil and mungbean seeds were treated with Provax $200 \mathrm{~W} P$ at the rate of $3 \mathrm{~g} \mathrm{~kg}^{-1}$ seed as a precaution against seedling blight and foot rot. For aphid control on mustard, Actara 25 WG @0.2 g/L of water was applied while Emamectin Benzoate (Proclaim 5 SG) was applied for the control of pod borer of mustard. Malathion (Fyfenon 57EC) was applied at the rate of $1.12 \mathrm{~L}$ for the control of leaf roller (Cnaphalocrocis medinalis), green leaf hopper (GLH; Nephotettix virescens), thrips (Thrips tabaci), hispa (Dicladispa armigera) of paddy rice and Carbaryl (Sevin 85SP) was applied at the rate of $1.70 \mathrm{~kg} \mathrm{ha}^{-1}$ for the control of rice bug. Other control measures and activities were typical of farmers' practice.

The increased residue retention increased the $\mathrm{N}$ recycled to the soil. To compensate for the $\mathrm{N}$ added with increased residue, we applied $5 \mathrm{~kg}$ and $10 \mathrm{~kg}$ less $\mathrm{N}$ as fertiliser $\mathrm{ha}^{-1}$ for mustard and irrigated rice crops, respectively, at Alipur site. Similarly, $10 \mathrm{~kg}, 10 \mathrm{~kg}$ and $5 \mathrm{~kg}$ less $\mathrm{N}$ as fertiliser $\mathrm{ha}^{-1}$ were applied for monsoon rice, wheat and jute, respectively, growing in soils of increased residue retained plots at Digram.

\subsection{Soil collection}

Intact soil cores were collected from field experiments during the period November 2014-June 2015 while sampling plants. Surface soil samples $(0-10 \mathrm{~cm})$ were collected from three locations in each plot by means of a push-type auger $(2.5 \mathrm{~cm}$ diam.). Soil cores collected in equal proportion from between the plants and from between the rows were combined. The field moist soil was then quickly cleaned of foreign (leaves, weeds, decayed branches, and roots removed after sampling) materials and extracted immediately (see below). Fifteen $g$ of soils from each sample was used for gravimetric moisture content determination. All measurements were carried out in triplicate.

\subsection{Plant $N$ analysis}

Jute, wheat, mustard and rice crops were destructively sampled at different sampling dates $(15,30,45,60,75,90$ and 100 days for mustard; 1, 15, 30, 45, 60, 75, 90 and 110 days for irrigated rice; 15, $30,45,60,75,90,105$ and 120 days for wheat, and 15, 25, 40, 55, 70, 
85 and 95 days for jute) to determine the biomass and $\mathrm{N}$ concentration in shoots. For the first two samplings of mustard, wheat and jute, representative $0.5 \mathrm{~m}^{2}$ quadrats of each plot was harvested; for the rest of the sampling events, 10 pre-marked plants were harvested with their roots; the samples were air-dried before oven-drying at $65-70{ }^{\circ} \mathrm{C}$ for $48 \mathrm{~h}$ and converted to dry matter $\mathrm{m}^{-2}$ based on the total plants $\mathrm{m}^{-2}$. For each biomass sampling of rice plants, four pre-marked hills including roots from each plot were harvested. The samples were airdried before oven-drying at $65-70{ }^{\circ} \mathrm{C}$ for $48 \mathrm{~h}$ then weights converted to dry matter plot $^{-1}$ based on the total hills plot $^{-1}$. The biomass of all crops was then converted to $\mathrm{tha}^{-1}$. Nitrogen concentrations in plant samples were determined by the Kjeldahl method (Page et al., 1989). Plant uptake of $\mathrm{N}$ was calculated by multiplying the concentration of $\mathrm{N}$ in plants by the dry biomass to give $\mathrm{N}$ content. The $\mathrm{N}$ uptake by each crop at different stages of their growth was converted to percentage of total $\mathrm{N}$ available at the respective stage (Eq. 1).

$\%$ of total available $\mathrm{N}=\frac{\text { The uptake of } N \text { by crops } \times 100}{\text { Total available } N}$

where total available $\mathrm{N}$ is as defined below.

\subsection{Nitrogen availability measurements}

Both $\mathrm{NH}_{4}-\mathrm{N}$ and $\mathrm{NO}_{3}-\mathrm{N}$ were extracted from the soils (10 cm depth) with $1 \mathrm{M} \mathrm{KCl}$ to determine the extractable mineral $\mathrm{N}$ in the soil sample (Jackson, 1956). The $\mathrm{NH}_{4}-\mathrm{N}$ and $\mathrm{NO}_{3}-\mathrm{N}$ were converted to $\mathrm{kg} \mathrm{ha}^{-1}$ based on the bulk density of the soil which was determined by core sampler method (Karim et al., 1988). Total $\mathrm{N}$ uptake values for crops at each soil sampling date (see above) were added to the amount of extractable $\mathrm{N}\left(\mathrm{NH}_{4}-\mathrm{N}+\mathrm{NO}_{3}-\mathrm{N}\right)$ recorded in soils to determine the amount of available $\mathrm{N}$. The latter values include residual mineral $\mathrm{N}$ from fertiliser applications.

\subsection{Nitrogen use efficiency (NUE)}

The NUEs of all crops grown in the present study were estimated separately by dividing grain or fibre yield of a crop by total $\mathrm{N}$ available during crop growing period (Han et al., 2015 and Xu et al., 2012) as shown below (Eq. 2):

$\mathrm{NUE}(\mathrm{kg}$ grain $/ \mathrm{kg} \mathrm{N})=\frac{\text { Grain yield }}{\text { Total available } N}$

\subsection{Description of models used}

To predict the rate of change in soil mineral $\mathrm{N}$, the following parallel first- and zero-order kinetic model was applied (Stanford and Smith, 1972; Griffin, 2008; Nannipieri and Paul, 2009):

$\mathrm{N}_{\mathrm{t}}=\mathrm{No}\left(1-\mathrm{e}^{-\mathrm{kt}}\right)+\mathrm{Nc}$ where $\mathrm{k}$ is the decomposition constant in $\mathrm{day}^{-1}$, No is the potentially mineralisable $\mathrm{N}$ in $\mathrm{mg} \mathrm{N} \mathrm{g}^{-1} \mathrm{~N}$ (PMN), $\mathrm{N}_{\mathrm{t}}$ is the $\mathrm{N}$ mineralisation after time, $\mathrm{t}$ and $\mathrm{Nc}$ is the decay rate of the resistant pool of $\mathrm{N}$ in soil per day. This model assumes that the SOM consists of an easily mineralisable pool of $\mathrm{N}$ that is mineralised exponentially according to first-order kinetics, and a more resistant fraction that is mineralised according to zero-order kinetics (Van Kessel et al., 2000).

Based on De Neve et al. (1996), a temperature correction function using the daily average temperature in the field was used to adjust the $\mathrm{N}$ availability rates obtained in the field to $\mathrm{mg} \mathrm{N}$ available per $\mathrm{m}^{2}$ per day $\left(\mathrm{k}_{\text {field }}\right)$.

\subsection{Statistical analysis}

The effects of crop establishment practices (SP, BP and CT) and residue retention (LR, HR) on total soil $\mathrm{N}$, crop $\mathrm{N}$ uptake, PMN and the decay rates were analysed by a split-plot analysis of variance. Where measurements were repeated over time, the data at each time was analysed as a separate experiment. All data regarding $\mathrm{N}$ dynamics were statistically assessed with SPSS software package version 21 (SPSS Inc., Chicago, IL, USA). Means were compared by using least significant difference (LSD) at $\mathrm{p}<0.05$.

\section{Results}

\subsection{Recycling of nitrogen through residue retention}

Nitrogen added through leaf litter fall and residue retention of all crops was $3-9 \mathrm{~kg} \mathrm{~N} \mathrm{ha}^{-1}$ more with HR than with LR $(\mathrm{p}<0.05)$ (Table 3). In case of monsoon rice residue retention, $\mathrm{N}$ recycled by HR was $6.1 \mathrm{~kg}$ higher than $\mathrm{N}$ recycled by LR. Among the crops, $\mathrm{N}$ recycling from jute leaf fall during crop growth and at harvest was 2-4 times higher than other crops.

\subsection{Total $N$ status in soils}

With SPHR, total soil-N concentrations at Alipur and Digram fields were significantly higher than other treatment combinations ( $\mathrm{p}<0.01$; Fig. 1). Strip planting with HR increased total $\mathrm{N}$ concentration by $62,34,21$ and $32 \%$ relative to CTLR, SPLR, BPLR and CTHR, respectively. Total soil-N concentration ranged from 0.53 to $0.86 \mathrm{~g} \mathrm{~kg}^{-1}$ at Alipur and 0.49 to $0.75 \mathrm{~g} \mathrm{~kg}^{-1}$ at Digram. At Alipur, the SPHR, BPHR and BPLR treatment total $\mathrm{N}$ stocks were 1.17, 1.12 and $1.03 \mathrm{Mg} \mathrm{N} \mathrm{ha}^{-1}$, which were significant higher than respective $\mathrm{N}$-stocks of soils under CTHR, CTLR and SPLR. At Digram, SPHR also had higher $\mathrm{N}$-stocks (1.05 Mg ha ${ }^{-1}$ ) than other treatment combinations (p < 0.05), and was followed by BPHR with $0.97 \mathrm{Mg} \mathrm{ha}^{-1} \mathrm{~N}$ at $0-10 \mathrm{~cm}$ soil. Among the two sites, the $\mathrm{N}$ stocks were higher at Alipur $(1.0 \mathrm{Mg}$ $\mathrm{ha}^{-1}$ ) than at the Digram site $\left(0.89 \mathrm{Mg} \mathrm{ha}^{-1} ; \mathrm{p}<0.05\right)$.

Table 3

Nitrogen content $\left(\mathrm{kg} \mathrm{ha}^{-1}\right)$ in above ground crop residue retention at Alipur and Digram over the three growing seasons of crops in the rice-based cropping systems (the values for jute crop include litter fall).

\begin{tabular}{|c|c|c|c|c|c|c|}
\hline \multirow[t]{2}{*}{ Treatments } & \multicolumn{3}{|l|}{ Alipur } & \multicolumn{3}{|l|}{ Digram } \\
\hline & Monsoon rice & Mustard & Irrigated rice & Monsoon rice & Wheat & Jute \\
\hline CTLR & 7.20 & 4.02 & 7.20 & 6.40 & 6.9 & 26.7 \\
\hline CTHR & 12.2 & 11.1 & 13.3 & 13.4 & 13.5 & 32.7 \\
\hline SPLR & 7.70 & 4.59 & 7.00 & 6.60 & 7.80 & 28.8 \\
\hline SPHR & 14.5 & 13.5 & 14.4 & 13.6 & 14.4 & 33.6 \\
\hline BPLR & 7.70 & 4.61 & 6.70 & 7.10 & 6.80 & 27.1 \\
\hline BPHR & 14.0 & 13.6 & 14.3 & 13.6 & 13.4 & 30.9 \\
\hline$L S D_{0.05}$ & $1.28^{* *}$ & $1.54^{*}$ & $2.33^{*}$ & $0.92^{* * *}$ & $1.67^{*}$ & $1.53 *$ \\
\hline
\end{tabular}

* Significant at $5 \%$ level of significance.

** Significant at $1 \%$ level of significance. 

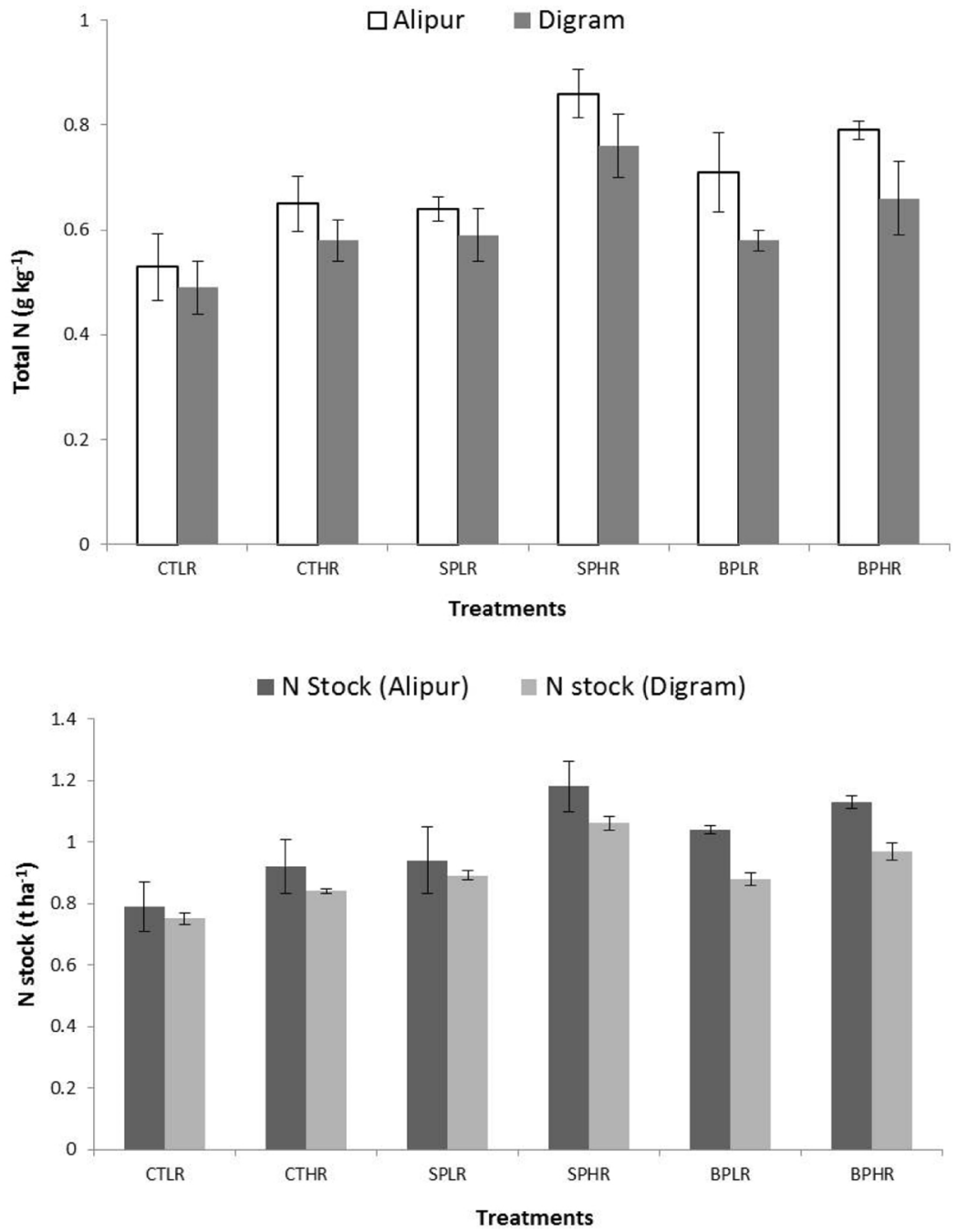

Fig. 1. Soil $\mathrm{N}$ status and stocks $(0-10 \mathrm{~cm})$ after 14 crops at Alipur and 13 crops at Digram under different crop establishment and crop residue retention practices. Nitrogen stocks were calculated from soil $\mathrm{N}$ concentrations and bulk density. [Abbreviations: BP bed planting, CT - conventional tillage, and SP - strip planting; HR - increased residue retention and LR - farmers' practice. Each marker point represents mean $(n=3)$ and vertical bars indicate standard error of the mean $( \pm)$. $\mathrm{LSD}_{0.05}$ for tillage, residue retention and their interactions (total $\mathrm{N}$ ) at Alipur and Digram were 0.07 and ns, 0.06 and $0.07 \& 0.08$ and 0.08 , respectively. $\mathrm{LSD}_{0.05}$ for tillage, residue retention and their interactions ( $\mathrm{N}$ stock) at Alipur and Digram were 0.18 and 0.07, 0.02 and 0.03, \& 0.17 and 0.08 , respectively.

\subsection{Biomass of the studied crops}

Aboveground biomass of the crops grown in the two fields over winter and early monsoon periods varied due to different crop establishment practices and residue retention levels $(\mathrm{p}<0.05)$. All the crop establishment practices with increased residue retention had higher biomass for all the crops except mustard which under SP and BP with LR had biomass higher than CTHR. For mustard at Alipur, and for wheat and jute crops at Digram, the biomass at harvest under SPHR was followed by biomass under BPHR. For rice at Alipur, biomass at harvest for SPHR was followed by the biomass at CTHR. At harvest, the lowest biomass of mustard and jute crops were recorded with CTLR, whereas biomass of wheat and rice was lowest under BPLR (Fig. 2)

\subsection{Nitrogen availability}

Cumulatively available $\mathrm{N}$ in soils varied with location, crop species and season $(\mathrm{p}<0.05)$. However, the cumulative $\mathrm{N}$ availability in the soils with HR was significantly higher $(p<0.05)$ than with LR (Fig. 3 ).

\subsubsection{Under mustard and rice crops cultivation}

In soils during the mustard crop, SP with HR had $17 \%$ less cumulative $\mathrm{N}$ available than CTHR ( $\mathrm{p}<0.05$ ). Conventional tillage with HR had $21 \mathrm{~kg}$ and $15 \mathrm{~kg}$ higher $\mathrm{N} \mathrm{ha}{ }^{-1}$ season $^{-1}$ than the levels of $\mathrm{N}$ available from soils under SPHR and BPHR, while SPLR and BPLR had
38 and $27 \mathrm{~kg} \mathrm{~N} \mathrm{ha}^{-1}$ season $^{-1}$ less available than CTHR practice at the end of the mustard season (Fig. 3).

With HR, the uptake of $\mathrm{N}$ by mustard, as a percent of $\mathrm{N}$ available, was generally higher than that under the same crop establishment practices with low residue retention $(\mathrm{p}<0.05)$ up to 30 DAS but thereafter the pattern was inconsistent among crop establishment types (Fig. 4 and Fig. A1 in Appendix A). The uptake by mustard of available $\mathrm{N}$ ranged from 10 to $17 \%$ at 15 DAS, $31-49 \%$ at 30 DAS and $55-73 \%$ at 45 DAS and beyond. Up to 30 DAS, mustard relative $\mathrm{N}$ uptake by CT was comparable to SP establishment but thereafter relative $\mathrm{N}$ uptake lagged behind that by SP.

In soil growing rice, cumulative $\mathrm{N}$ availability under BPHR and CTHR were the highest $\left(149 \mathrm{~kg} \mathrm{~N} \mathrm{ha}{ }^{-1}\right.$ season $\left.^{-1}\right)$ at harvest. Non-puddled transplanting of rice seedlings with LR had $24-30 \%$ less $\mathrm{N}$ available than CTHR and BPHR, respectively. Soils under non-puddled transplanting of rice seedlings with HR has $11 \%$ lower cumulative $\mathrm{N}$ available than soils under CTHR.

Up to 30 DAS, the $\mathrm{N}$ availability to rice was slower in soils under SPHR and BPHR than CTHR treatments but from 45 days after transplanting (DAT), the rate of increase in $\mathrm{N}$ availability exceeded that of CTHR (Fig. 3). Cumulative available N in rice soils under SPHR, CTHR and BPHR were significantly higher than with LR combinations.

Up to 15 DAS, the uptake of $\mathrm{N}$ by rice, as a percent available $\mathrm{N}$, was lower under CT with LR and HR than the uptake by crops under BP and SP with LR and HR (Fig. 4 and Fig. A1 in Appendix A). Uptake of 

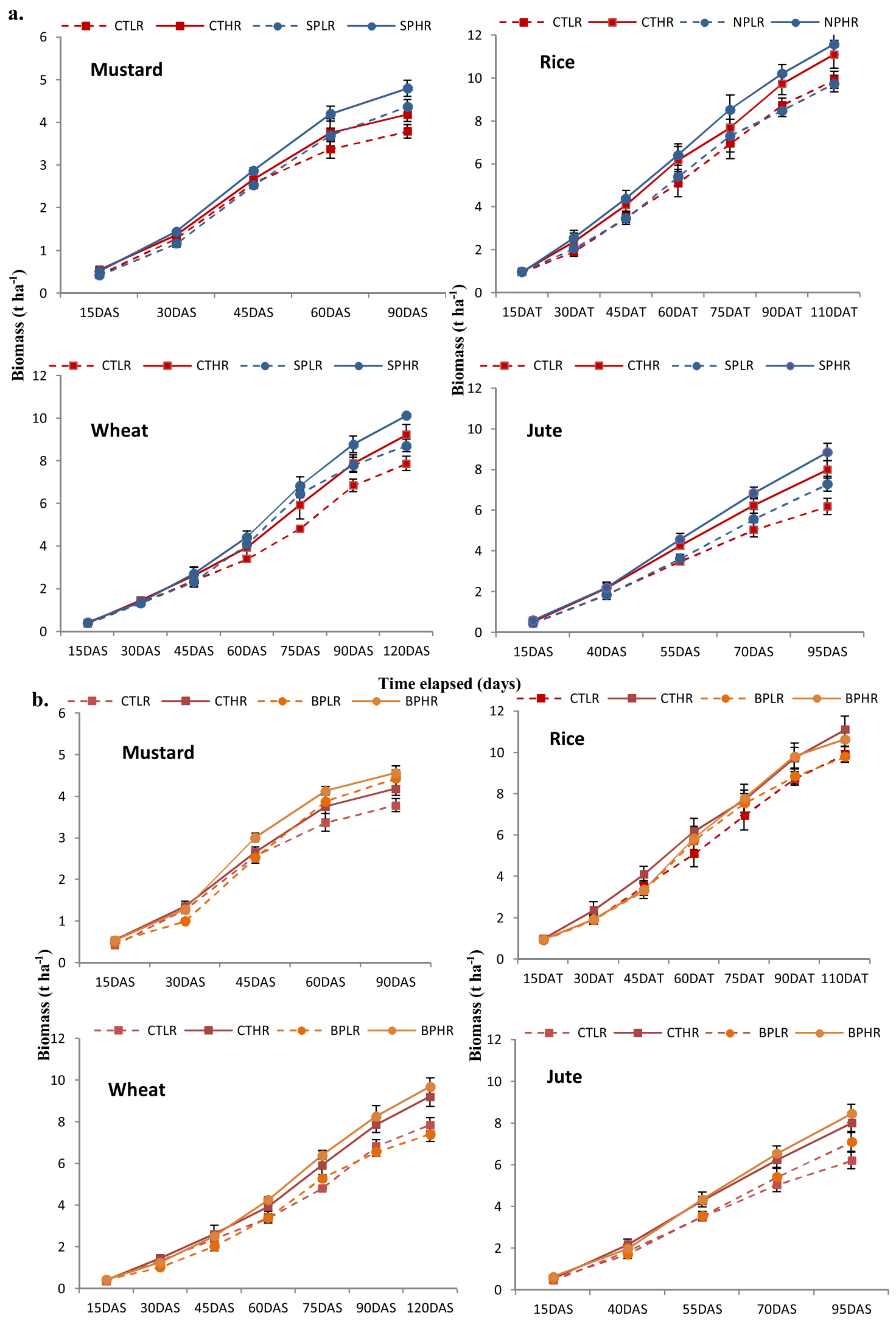

Time elapsed (days)

Fig. 2. Aboveground biomass of the studied crops over time under different crop establishment practices and residue retention levels (2a-SP versus CT and 2b-BP versus CT with their residue retention practices). Mustard and rice were grown at Alipur in winter and early summer season, respectively, while wheat and jute were grown in Digram in winter and early summer seasons, respectively. [Abbreviations: BP - bed planting, CT - conventional tillage, and SP - strip planting; HR increased residue retention and LR - farmers' practice. DAS-Days after sowing; DAT-days after transplanting]. Each marker point represents mean (n $=3$ ) and vertical bars indicate \pm standard error of the mean. 


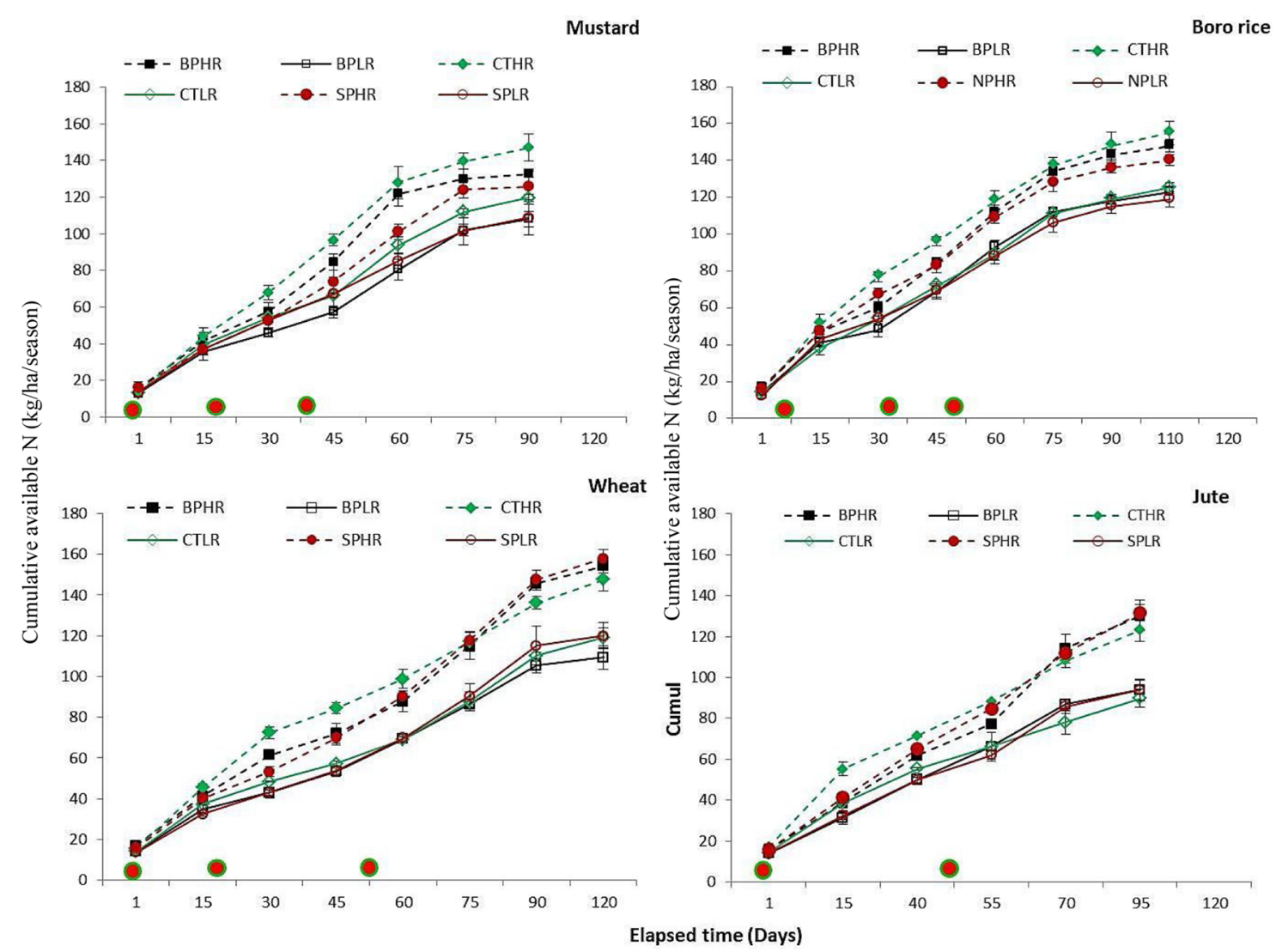

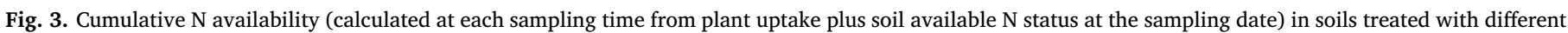

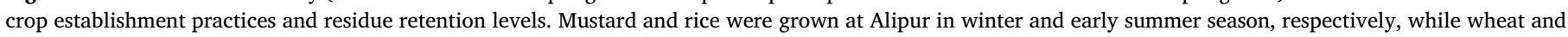

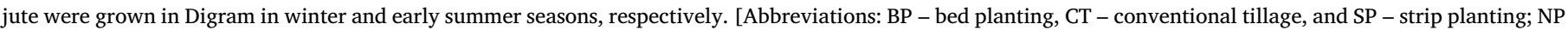

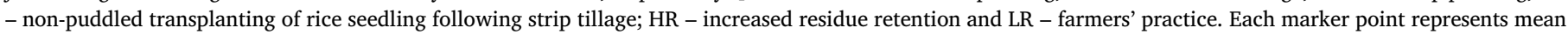

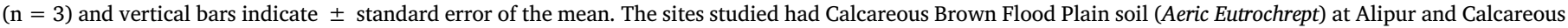
Dark Grey Floodplain soil (Aeric Eutrochrept) in Digram. (O) denotes dates of $\mathrm{N}$ fertiliser application in splits.

available N (\%) by non-puddled transplanting of rice seedlings with HR was consistently higher than with LR, but for BP and CT, the residue effects were inconsistent. The final relative $\mathrm{N}$ uptake percent of available $\mathrm{N}$ by rice were higher with SPHR than CTHR (Fig. 4 and Fig. A1 in Appendix A).

\subsubsection{Under wheat and jute crop cultivation}

With HR, SP and BP had 10.3 and $6.6 \mathrm{~kg} \mathrm{~N}^{-1}$ higher cumulative $\mathrm{N}$ available than CTHR ( $\mathrm{p}>0.05$; Fig. 3). Overall, the crop establishment practices with HR had significantly higher cumulative $\mathrm{N}$ available from soils under wheat and jute than the same crop establishment practices with LR ( $\mathrm{p}<0.05$; Fig. 3). Strip planting with HR had 45, 33 and $31 \%$ higher available $\mathrm{N}$ than CTLR, BPLR and SPLR, respectively. Though initial $\mathrm{N}$ availability was higher with CTHR, after 60 DAT the availability decreased relative to that with SPHR and BPHR (Fig. 3).

The uptake of $\mathrm{N}$ as a $\%$ of available $\mathrm{N}$ by wheat was higher with $\mathrm{CT}$ and SP than BP from 30 to 60 DAS regardless of residue retention level. The $\%$ uptake of available $\mathrm{N}$ by wheat crop was $9-15 \%$ at 15 DAS, $18-27 \%$ at 30 DAS, $32-44 \%$ at 45 DAS and 50-70\% at 60 DAS and beyond. The percent uptake of available $\mathrm{N}$ by the wheat under CT and SP with LR and HR reached a peak at 60 DAS and declined thereafter. Until 60 DAS for wheat, the N uptake by BPHR was significantly lower than CTHR and SPHR (by 8-18\%). At the later stage of sampling, the percent uptake of available $\mathrm{N}$ was higher with crops grown under BPLR, CTHR and SPHR. The percent $\mathrm{N}$ uptake of available $\mathrm{N}$ by wheat until 45 DAS was higher in crops under SPHR followed by SPLR, CTLR and CTHR, respectively (Fig. 4 and Fig. A1 in Appendix A).
Jute growing in BPHR and SPHR soils had the highest final available $\mathrm{N}$ (132 $\mathrm{kg} \mathrm{N} \mathrm{ha}^{-1}$ season $^{-1}$ ) (Fig. 3). Up until 55 DAS, however, N availability in soils under CTHR was higher but thereafter the availability decreased compared to SPHR and BPHR. At harvest, cumulative $\mathrm{N}$ availability in soils under SP, BP and CT with HR exceeded that with LR ( $p$ > 0.05; Fig. 3). Among low residue retention treatments, CTLR had the lowest amount of available $\mathrm{N}(\mathrm{p}>0.05)$.

In the case of jute, the percent uptake of available $\mathrm{N}$ by crops in $\mathrm{CT}$ was always lower until 90 DAS than with SP and BP (Fig. 4 and Fig. A1 in Appendix A).

\subsection{Nitrogen use efficiency}

The NUE varied due to crop establishment and residue retention practices singly, except wheat at Digram which had varied NUE due to combined effects of crop establishment and residue retention practices. Among the crop establishment practices, SP practice had higher $\mathrm{N}$ use efficiency for jute (31.9 kg fibre/ $\mathrm{kg} \mathrm{N}$ ), mustard (14.4 kg grain $/ \mathrm{kg} \mathrm{N}$ ) and irrigated rice $(52.2 \mathrm{~kg}$ grain $/ \mathrm{kg} \mathrm{N})$. On the other hand, HR had lower NUE for all crops relative to LR (Table 4).

\subsection{Nitrogen dynamics}

Soil N availability data of Alipur and Digram soils were fitted with a parallel-first and zero-order kinetic model. The $\mathrm{N}$ availability process was adequately described $\left(\mathrm{R}^{2} \geq 0.95\right)$ and standard errors were very low (Table 5). 


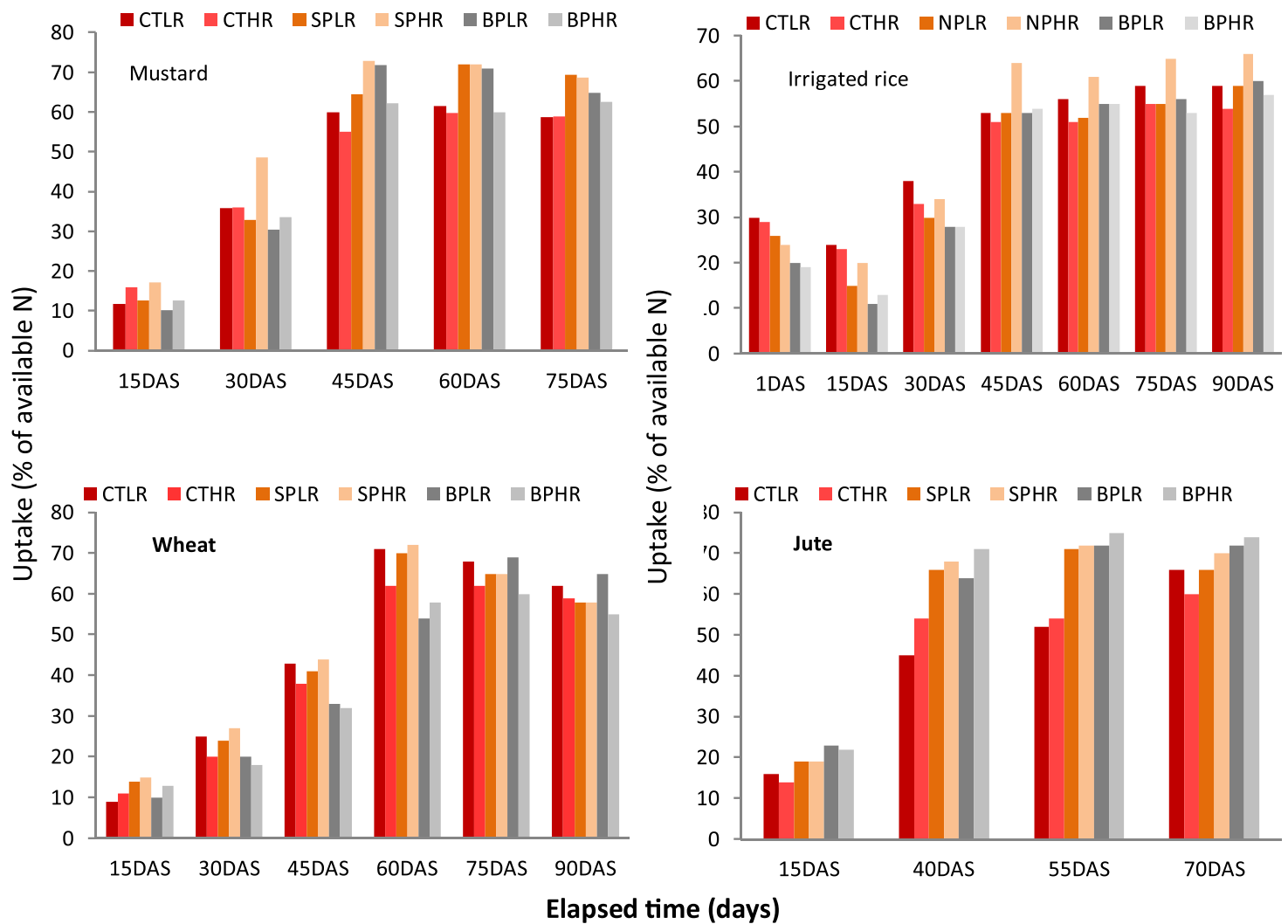

Fig. 4. Effect of crop establishment and residue retention practices on nitrogen uptake as a $\%$ of $\mathrm{N}$ available (the uptake of $\mathrm{N}$ by crops at different stages were calculated as percentage of total available N) over the growing season (except harvest) for mustard and irrigated rice at Alipur and wheat and jute at Digram. The LSD values for mustard crop were $0.71^{* *}$ (15DAS), $1.43^{* *}$ (30 DAS), $1.82^{* *}$ (45 DAS), 1.42** (60 DAS) and 1.1** (75DAS) of mustard; the LSD values for rice crop were $0.82^{\text {ns }}$ (15DAS), 1.16** (30DAS), 1.08** (45DAS), 2.33** (60DAS), 2.02** (75DAS), and 1.41** (90DAS); the LSD values for wheat crop were 2.95 ns (15DAS), $1.25^{* *}$ (30DAS), 1.91** (45DAS), 2.82** (60DAS), 0.97** (75DAS) and 1.03** (90DAS); the LSD values for jute crop were 1.21** (15DAS), 4.0* (40DAS), 4.15 ${ }^{\text {ns }}$ (55DAS) and 2.65** (70DAS). [Abbreviations: BP - bed planting, CT - conventional tillage, and SP - strip planting; NP - strip-based non-puddled transplanting of rice seedlings; HR - increased residue retention and LR - farmers' practice. The sites studied had Calcareous Brown Flood Plain soil (Aeric Eutrochrept) at Alipur and Calcareous Dark Grey Floodplain soil (Aeric Eutrochrept) at Digram. ns- denotes significant. ** denotes significant at $1 \%$ level of significance. * denotes significant at $5 \%$ level of significance.

Table 4

Nitrogen use efficiency ( $\mathrm{kg}$ seed or grain or fibre $/ \mathrm{kg}$ of $\mathrm{N}$ ) of wheat and jute grown at Digram, Godagari and mustard and irrigated rice at Alipur, Durgapur of Rajshahi district. The NUEs of crops were estimated by dividing grain or fibre yield of a crop by total $\mathrm{N}$ available during crop growing period.

\begin{tabular}{|c|c|c|c|c|}
\hline \multirow[t]{2}{*}{ Treatments } & \multicolumn{2}{|c|}{ Digram, Godagari } & \multicolumn{2}{|c|}{ Alipur, Durgapur } \\
\hline & Wheat & Jute & Mustard & Irrigated rice \\
\hline CT & 32.8 & 27.7 & 12.4 & 48.7 \\
\hline SP & 37.2 & 31.9 & 14.4 & 52.2 \\
\hline $\mathrm{BP}$ & 39.2 & 31.6 & 13.7 & 45.3 \\
\hline S.E.M. ( \pm ) & ns & 0.32 & 0.27 & 0.68 \\
\hline LR & 40.3 & 34.1 & 14.0 & 51.1 \\
\hline $\mathrm{HR}$ & 32.5 & 26.7 & 12.9 & 46.4 \\
\hline S.E.M. ( \pm ) & 0.41 & 0.37 & 0.10 & 0.53 \\
\hline CTLR & 34.9 & 31.5 & 12.8 & 51.7 \\
\hline CTHR & 30.7 & 24.2 & 11.9 & 45.6 \\
\hline SPLR & 41.0 & 34.9 & 14.9 & 53.7 \\
\hline SPHR & 33.4 & 28.3 & 13.8 & 50.7 \\
\hline BPLR & 45.0 & 35.9 & 14.4 & 47.8 \\
\hline BPHR & 33.3 & 27.6 & 13.0 & 42.8 \\
\hline S.E.M. ( \pm ) & 1.74 & ns & ns & ns \\
\hline Error D.F. & 6 & 6 & 6 & 6 \\
\hline
\end{tabular}

Here, CT-Conventional tillage/puddling; SP-Strip planting (non-puddled transplanting in strip for rice); BP-Bed planting (non-puddled transplanting on bed for rice).

LR-Low residue retention; HR-Increased residue retention.

S.E.M.-Standard error of mean; D.F.-Degrees of freedom.
3.6.1. Easily mineralisable $\mathrm{N}$ pool (No) and mineralisation rate constant of the easily mineralisable $N$ pool

In mustard growing soils, for SP with HR, the easily mineralisable $\mathrm{N}$ pool (No) was 1.15 and 1.13 times higher than CTHR and BPHR. Moreover, the No under SPHR was 1.8 times higher than CTLR practice ( $\mathrm{p}<0.05$ ). Even with LR, SP had higher No than CT. The higher residue retention level had the higher No. In case of decay rate of No, CT with HR had the highest decay rate while SPLR had the lowest decay rate. The decay rates of the resistant $\mathrm{N}$ pool showed the opposite results of the decay rates of the No pool (Table 5).

At Alipur after mustard, in soils growing rice, non-puddling with HR had the highest potentially mineralisable $\mathrm{N}$ (No) which was followed by CTHR and BPHR (Table 5). However, the decay rate of No under NPLR and CTLR were higher than decay rates of No under NPHR. Decay rates of No under BPHR were more than double (2.34 times \& 2.75 times) the decay rates of No under SPHR and CTHR, respectively. Increased residue retention had lower decay rates $(p<0.05)$. The decay rates of resistant $\mathrm{N}$ pool day ${ }^{-1}$ in rice growing conditions were also higher in soils under BP than CT and SP regardless of residue retention practices (Table 5).

At Digram for the wheat crop, the crop establishment effect on $\mathrm{N}$ mineralisation parameters varied with residue retention level in the Grey Terrace soil $(\mathrm{p}<0.05)$. The highest No value was under SPHR, followed by BPHR (37 \% lower than SPHR) and then CTHR (52 \% lower than SPHR) practices. Potentially mineralisable soil-N under SPHR was 85, 59, and $57 \%$ higher than CTLR, SPLR and BPLR, respectively. The lowest No was found in soils under CTLR, but the decay rate of No was 


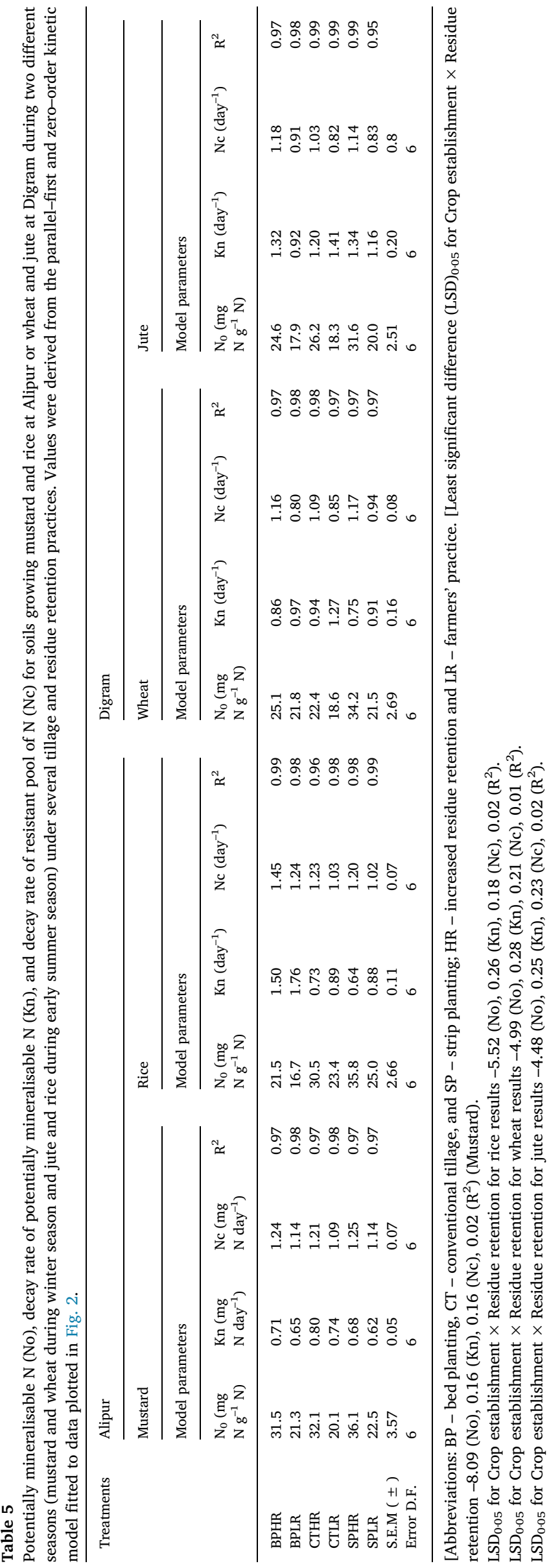

higher in soils under CT irrespective of residue retention practices while the lowest decay rate was found in soils under SP (Table 5). Conventional tillage with LR had the highest decay rate of No which was followed by BPLR. Strip planting with LR and BPLR had 40 and $31 \%$ lower decay rate than CTLR, respectively. Strip planting with HR had the highest decay rate of Nc while the second lowest decay rate was found in BPHR (Table 5).

For jute the highest No in Grey Terrace soil was for SPHR (31.6 $\left.\mathrm{mg} \mathrm{N} \mathrm{g}^{-1} \mathrm{~N}\right)$ followed by CTHR $\left(26.2 \mathrm{mg} \mathrm{N} \mathrm{g}^{-1} \mathrm{~N}\right.$ ) while BPHR had the lowest No. Strip planting with HR had 29 and $21 \%$ higher No than CTHR and BPHR, respectively ( $\mathrm{p}<0.05$ ) while the lowest No was found in soil under BPLR, followed by CTLR and SPLR, respectively. On the other hand, CTLR practices had the highest decay rate of No with values being 1.2 and 1.5 times higher than SPLR and BPLR, respectively (Table 5). The decay rates of resistant $\mathrm{N}$ pool day ${ }^{-1}$ in jute growing conditions was highest in soils under BP with HR ( $<<0.05$; Table 5), followed by SPHR and CTHR, respectively ( $p>0.05$ ), but decay rate in BPHR was significantly higher than the decay rate in BPLR, SPLR and CTLR, respectively $(\mathrm{p}<0.05)$.

\section{Discussion}

\section{1. $N$ stocks}

Strip planting with increased residue retention sequestered more total $\mathrm{N}$ in soil $(0-10 \mathrm{~cm})$ than the current practice (conventional tillage with low residue retention) under two cropping systems, which we attribute to the slowing of the decomposition of residues but despite this, the total $\mathrm{N}$ uptake by crops of the rice-based cropping systems was the same or increased (Table 5 and Figs. 1-3). The changes in total $\mathrm{N}$ and decomposition can be attributed to the effects of both the minimum soil disturbance including the non-puddled rice seedling establishment practice, and the increased residue retention in the rice-based triple cropping CA systems (Haque et al., 2016 and Alam et al., 2016a). Crop establishment methods especially tillage effects on the concentrations of total $\mathrm{N}$ in soil followed a similar pattern in both rice-dominated (Alipur) and rice-based (Digram) cropping systems ( $\mathrm{p}<0.05)$. In our study, the $\mathrm{N}$ stock in soil $(0-10 \mathrm{~cm})$ was greater under SPHR by $48 \%$ at Alipur and by $41 \%$ at Digram than under CTLR after 12-14 crops. This difference can be attributed to the lower degree (less than $25 \%$ ) of soil disturbance which facilitates accumulation of $\mathrm{N}$ in organic and inorganic forms ( $\mathrm{N}$ in soil organic matter, in newly added crop residues and in freshly added litterfall) by regulating their decomposition and loss processes (Islam, 2016; Xue et al., 2015 and Kader et al., 2016). Furthermore, total $\mathrm{N}$ enrichment in soil is attributed to slower decomposition of residue retained or anchored between rows due to limited contact between soil microorganisms and the minimally-disturbed surface soil (Islam, 2016; Dikgwatlhe, 2014; Xue et al., 2015).

The greater amount of residue return in soils under HR also increased TN in soils by recycling greater amounts of organic $\mathrm{N}$ ( $\mathrm{p}<0.05$ ) to the soil. Almost half of the rice residues, litter-fall and all of the non-rice residues were retained directly on the soil under the HR practice which contributes an extra $40 \mathrm{~kg} \mathrm{ha}^{-1}$ and up to $60 \mathrm{~kg} \mathrm{ha}^{-1}$ of N input per year under HR in rice- dominant (Alipur) and rice-based systems (Digram), respectively (Table 3). Notwithstanding the decrease in fertiliser $\mathrm{N}$ applied with HR (see Table 3), the increased amounts of recycled $\mathrm{N}$ under HR explain most of the greater $\mathrm{N}$ accumulation in soils as also found after 7 crops in the present experiments (Islam, 2016). In contrast, CA cropping systems in dry-land agriculture that produce lower amounts of residues annually, the residue retention was slower to boost TN in soil (Guo et al., 2015). Islam et al. (2016) found N stocks increased in both legume- and cereal-dominated systems at $0-7.5 \mathrm{~cm}$ depth within three years ( 7 crops) of residue retention at increased levels. With LR in our study, the annual accumulation rates of $\mathrm{N}$ at Alipur and Digram were 16.7 and $10.4 \mathrm{~kg} \mathrm{ha}^{-1}$, respectively, while with 
$\mathrm{HR}$, they were 35 and $30 \mathrm{~kg} \mathrm{~N} \mathrm{ha}^{-1} \mathrm{yr}^{-1}$ at Alipur and Digram, respectively. Islam (2016) found that during the initial year of the study, the $\mathrm{N}$ accumulation rate was 3.6 times higher with HR compared to LR at Alipur. The higher $\mathrm{N}$ accumulation rate with HR found by Islam (2016) than that in our study can be attributed to the short-term versus medium-term effects of CA (Alam et al., 2016b; Ghimire et al., 2017; Yadav et al., 2017)

The SPLR and SPHR treatments also outperformed the BPLR and BPHR treatments in increasing total $\mathrm{N}$ in soils. In the present study, the permanent, shallow raised beds were reshaped two or three times in a year. This process not only disturbed the soils but also incorporated nearly $30-40 \%$ of the residues left on the surface, thereby enhancing the mineralization and loss of SOC and N compared to the SP/NP treatment in which residues remained on the soil surface (Sapkota et al., 2017).

\section{2. $N$ availability}

During the first 15-60 days of growth of all crops, CTLR had consistently higher $\mathrm{N}$ availability than other practices. Conventional tillage with HR at 15 DAS of mustard had 6-24 \% higher available N, 18-49\% higher at 30 DAS and 14-67 \% higher at 45 DAS than other treatments. On the other hand, for the rice crop, CTHR maintained higher $\mathrm{N}$ availability up until 75 days ( $<<0.05)$ : for wheat and jute, CTHR maintained higher $\mathrm{N}$ availability up to 60 DAS ( $\mathrm{p}<0.05$ ). By contrast, at harvest, SPHR and BPHR had the highest cumulative N availability ( $p>0.05$ ). Repeated disturbance of soils with CT and incorporation of crop residues along with basal application of $\mathrm{N}$ fertilisers, higher soil temperature and higher microbial activity probably account for higher $\mathrm{N}$ availability during the early stages of growth in CT (Raiesi, 2006; Wright and Reddy, 2001; Busari et al., 2015). The slowing down of $\mathrm{N}$ availability rate over time under CTHR suggests that either the readily mineralisable pool of $\mathrm{N}$ is depleted after the initial stage of crops or that there were greater $\mathrm{N}$ losses under CTHR (Alam et al., 2016a, and 2018). By contrast, it is likely that the crop residues, either standing or retained on the surface of soil slowed initial $\mathrm{N}$ availability in SP due to limited contact with soil microorganisms. In addition, the basal $\mathrm{N}$ fertilizer dose was evidently not sufficient to accelerate the $\mathrm{N}$ mineralisation from the mass of $\mathrm{N}$-poor crop residues when they were not incorporated.

The variations in soil temperature and moisture (data not presented) recorded in soils at both the sites under SP, BP and CT with LR and HR also probably affected $\mathrm{N}$ availability in soils. Mean soil temperatures were different for all treatments during the two seasons of cropping, with CTLR being the highest and BPHR the lowest (Alam et al., 2018). Even after crop 7 in these long term experiments, Islam (2016) recorded the similar increases in soil temperature with CT. More $\mathrm{N}$ is released when tillage coincides with periods of high soil temperature and/or moderate soil moisture (Pekrun et al., 2003; Islam, 2016). Compared with CT, SP and BP with HR created cooler soil, resulting in slower initial release of N from SOM (Doran and Parkin, 1994; Nicolardot et al., 1994). The increasing temperature at the end of winter season under SP with HR could explain in part the enhanced $\mathrm{N}$ availability found during later stages of crop growth in our study. In summary, the differences in cumulative $\mathrm{N}$ availability in soils among tillage and residue retention practices can be attributed to differences in soil $\mathrm{N}$ levels, decomposition rates of soil organic $\mathrm{N}$, recyclable $\mathrm{N}$ content in residues and the temperature and water content in soil.

Increased residue retention, which is advocated for CA practice, increased $\mathrm{N}$ availability under all crops at both sites and cropping system ( $\mathrm{p}<0.05$ ) after $12-14$ crops. Islam (2016), after 7 crops, also found similar results for available $\mathrm{N}$ levels, in a legume dominated-rice based cropping systems with a positive $\mathrm{N}$ balance. This suggests that over time between crop 7 and crops 13-14, the accumulation of soil organic $\mathrm{N}$ stocks have also increased the net $\mathrm{N}$ available during crop growth. The increased cumulative $\mathrm{N}$ availability in soils under SPHR and BPHR can also be attributed to improved soil $\mathrm{N}$ status, and to the availability of substrate $\mathrm{N}$ through slow decomposition of previous crop residue in wheat and jute fields throughout the season and from fresh litter fall from jute plants (Buresh et al., 2008). On average, at Alipur, the annual recycled $\mathrm{N}$ was $23.1,36.6$ and $22.9 \mathrm{~kg}$ higher/ha with CTHR, SPHR and BPHR than CTLR, SPLR and BPLR, respectively, while, at Digram, the recycled $\mathrm{N}$ were $19.6,18.4$ and $16.9 \mathrm{~kg}$ higher/ha than CTLR, SPLR and BPLR, respectively. Had the $\mathrm{N}$ fertilizer been applied at an equal rate with LR and HR (Table 2), the cumulative $\mathrm{N}$ availability would have been even higher with HR. The daily $\mathrm{N}$ availability rates in HR over the growing seasons of mustard and rice were 1.43 and $1.32 \mathrm{~kg}$ $\mathrm{ha}^{-1}$, respectively, which were 20 and $21 \%$ higher than the rates with LR (Fig. 5). The daily rates in HR in wheat and jute were 1.31 and $1.38 \mathrm{~kg} \mathrm{ha}^{-1}$, respectively, which were 34 and $42 \%$ higher than the rate found in LR.

Residue composition varied among species and this too had a major influence on the rate of decomposition and subsequently on soil $\mathrm{N}$ turnover (Raiesi, 1998, 2006). Mustard residues have $11 \%$ higher cellulose and $15 \%$ higher lignin than wheat residues, while rice residues have $71 \%$ higher cellulose and $63 \%$ lower lignin than jute residues (Alam et al., 2018). Mustard and jute leaf litter had higher $\mathrm{N}$ content (C:N ratios 47 and 38, respectively; Alam et al., 2018) and greater $\mathrm{N}$ recycled compared to wheat and rice residues (Table 3 ). The higher $\mathrm{N}$ recycled by mustard residue might contribute to higher $\mathrm{N}$ availability in soils following irrigated rice (by $11 \mathrm{~kg} \mathrm{~N}$ ha $^{-1}$; Fig. 2) and higher uptake by the subsequent crop (4.5 $\mathrm{kg} \mathrm{N}^{-1}$; Fig. 3).

Chen et al. (2014) reported that generally crops absorb approximately $70-80 \%$ of their $\mathrm{N}$ during the vegetative growth but without enough available $\mathrm{N}$ in soil during the vegetative growth stage, the yield will be reduced. Conversely, if excessive $\mathrm{N}$ is available during the stage greater $\mathrm{N}$ losses are a risk. While CT increased availability up to 60-75 DAS, subsequent uptake and availability rate was slower in CT than SP. It is possible that more $\mathrm{N}$ loss occurred under CT. For example, uptake by jute at CTHR was very low in relation to the amount of $\mathrm{N}$ available. The uptake of $\mathrm{N}$ by jute grown under CTHR was $5 \%, 14 \%, 18 \%, 10 \%$ and $9 \%$ lower than NPHR at 15, 40, 55, 70 and 95 DAS, respectively.

In addition to the increased soil $\mathrm{N}$ stock under HR with $\mathrm{SP}$, the increased crop $\mathrm{N}$ uptake can be attributed to improved soil water storage in the dry season which may enhance soil $\mathrm{N}$ availability (Islam, 2016; Sapkota et al., 2017). However, there is some evidence that as previous residue rate increased, uptake of indigenous soil $\mathrm{N}$, but not fertilizer $\mathrm{N}$, is increased (Maskina et al., 1993). Indeed, in the present study, the amount of $\mathrm{N}$ fertiliser was decreased in HR plots, by the amount equivalent to the extra $\mathrm{N}$ added in residue. Hence despite no additional total $\mathrm{N}$ input and decreased fertiliser $\mathrm{N}$, overall $\mathrm{N}$ uptake was enhanced by HR. This suggests greater $\mathrm{N}$ use efficiency under SP and the possibility of decreased $\mathrm{N}$ fertiliser rates for crops under long term CA practice. The NUEs calculated for all crops in the present study (Table 4) support the suggestion. This needs further evaluation in the main crop rotations in Bangladesh.

Timsina et al. (2006) found the negative $\mathrm{N}$ balances and reduced $\mathrm{N}$ cycling were reversed with residue retention in monsoon rice-wheat-maize and monsoon rice-wheat-mungbean cropping systems after 3-4 years under subtropical conditions. Islam et al. (2016) also found that residue retention turned negative $\mathrm{N}$ balances into positive balances under a lentil-mung bean-monsoon rice rotation. By contrast, Boateng and Dennis (2000) showed that application of residue had no significant effect on $\mathrm{N}$ uptake by crops, while surface application of residue reduced $\mathrm{N}$ uptake and crop yield by $\mathrm{N}$ immobilisation (Soon and Lupwayi, 2012). It is likely that after 12-14 successive crops, as in the present study, the $\mathrm{N}$ immobilisation processes are suppressed due to the larger stock of soil organic carbon (Alam et al., 2018) and soil $\mathrm{N}$ (present study). Indeed the combined results of present study on $\mathrm{N}$ availability and $\mathrm{N}$ uptake suggest that the synchrony between $\mathrm{N}$ demand by the crops and $\mathrm{N}$ release under SP and HR was improved by slowing the initial availability rates (0-30 DAS) when crop demand is 

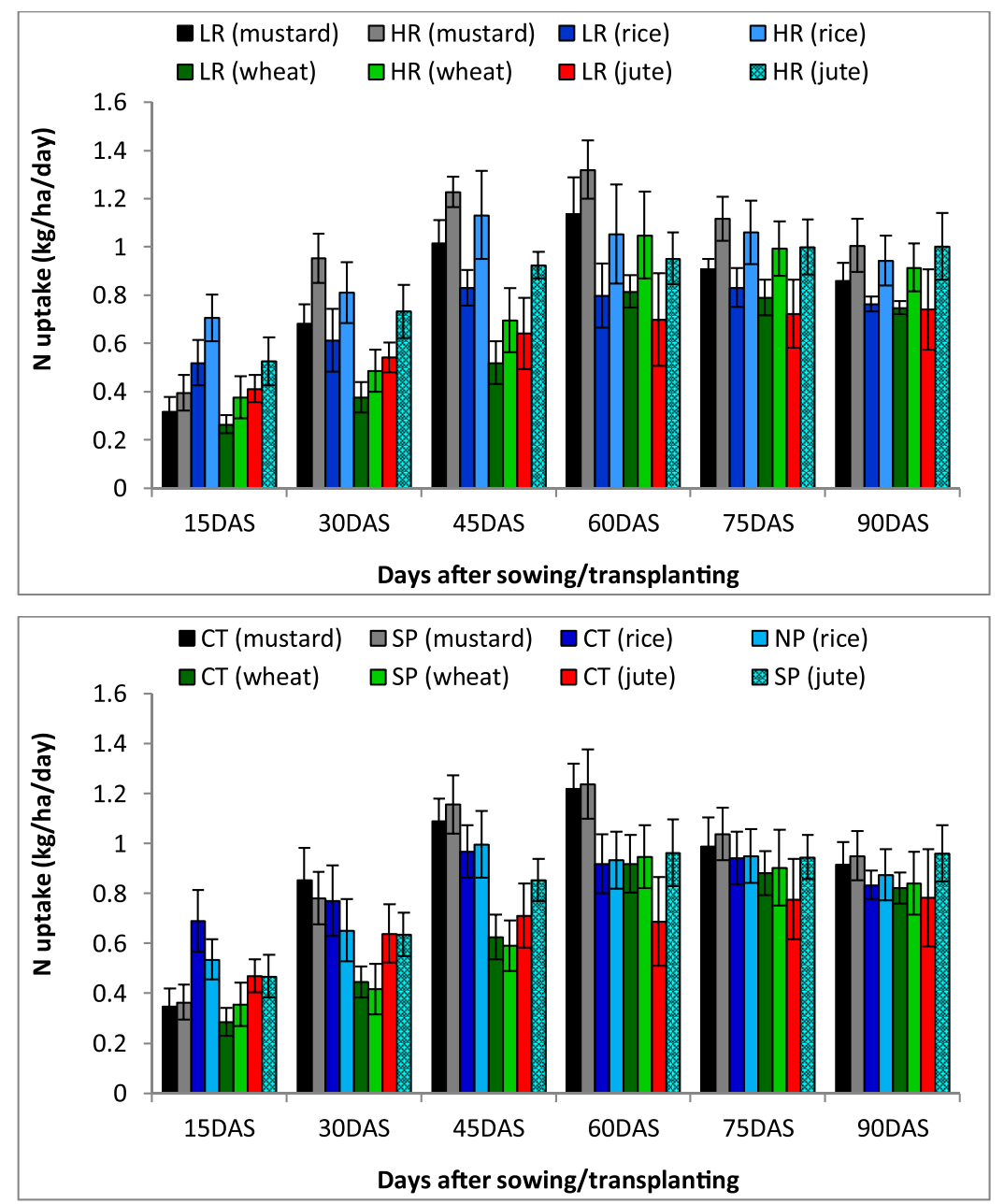

Fig. 5. Effect of residue level (above: low (LR)- farmers' practice and increased residue retention (HR)) and crop establishment practices (below: conventional and strip planting) on daily $\mathrm{N}$ uptake rate by all crops up to 90 days after sowing or transplanting at Alipur and Digram. Values are means of four replicates, averaged across soil disturbance treatments. Vertical bars indicate standard error of the mean $( \pm)$.

low (Figs. 4-5) and increasing $\mathrm{N}$ availability later when crop demand is greater. Improved synchrony between crop demand and soil $\mathrm{N}$ supply leads to more efficient recovery of residue $\mathrm{N}$ by $\mathrm{N}$ uptake (Becker et al., 1994). With the HR, the recoveries of $\mathrm{N}$ with SPHR, BPHR and CTHR in the present study were 16,14 and $14 \mathrm{~kg} \mathrm{ha}^{-1}$ greater relative to SPLR, BPLR and CTLR, respectively, for mustard which were equivalent to 111,100 and $95 \%$ of the residue $\mathrm{N}$ input by the previous monsoon rice (Table 3). The recoveries of $\mathrm{N}$ with SPHR, BPHR and CTHR were equivalent to 155,104 and $144 \%$ of the residue $\mathrm{N}$ input by the previous mustard crop for irrigated rice, respectively. The recoveries of $\mathrm{N}$ with SPHR, BPHR and CTHR for wheat were equivalent to 147, 96 and $95 \%$ of the residue $\mathrm{N}$ input by previous monsoon rice and 215, 164 and 118 $\%$ of the residue $\mathrm{N}$ input by previous wheat residue for jute at Digram. Among crops there were clearly differences in the contribution of previous residue to crop $\mathrm{N}$ uptake relative to fertiliser $\mathrm{N}$. Jute relied more on fertiliser $\mathrm{N}$ after wheat than mustard after monsoon rice. This reflects the different $\mathrm{N}$ demand of the crops, different $\mathrm{N}$ input from the previous crop's residue and different soil chemistry between wetland and aerobic soils. However, clearly long term retention of increased crop straw together with minimum soil disturbance compared to current farmers' practice increases $\mathrm{N}$ uptake by the crops after 12-14 crops at both the sites. The NUEs estimated by dividing the grain or fibre yield of crops by the total available $\mathrm{N}$ during the entire growth period of respective crop were a useful measure of the positive effect of CA practices on $\mathrm{N}$ availability (Table 4).

\subsection{Cycling of $N$ fractions under tillage and crop residue retention practices}

Strip planted soils had higher potentially mineralisable N (PMN) values than CT irrespective of the level of residue retained in soils. Together with the lower decay rates of PMN, the present results suggest that minimum soil disturbance in SP practices has altered $\mathrm{N}$ cycling by reducing the level of available $\mathrm{N}$ available to plants in the early growing season while increasing $\mathrm{N}$ use efficiency, especially later in the growing season. While the decay rate of PMN under CTHR was higher, the PMN level was lower as was total $\mathrm{N}$ uptake compared to SP and BP with HR in wheat and jute. This suggests that more available $\mathrm{N}$ is lost in CTHR or CTLR. Further research into losses via denitrification (Alam et al., 2016a, 2018), nitrate leaching, ammonia volatilisation or surface runoff are needed to clarify the underlying mechanisms for the present results (Palma et al., 1998; McGarry et al., 1987; Kader et al., 2016). Some other studies conducted with two tillage practices (CT and NT) found higher $\mathrm{N}$ loss through $\mathrm{NO}_{3}-\mathrm{N}$ leaching under CT due to increased $\mathrm{N}$ availability (Angle et al., 1993; Randall and Iragavarapu, 1995). Further research is needed in the cropping systems in the EGP to determine the relative rates and pathways of N loss in CT versus SP.

Nitrogen cycling also appeared to change under BP relative to CT. While the lowest PMN in soil was found in BP with residue retention, the decay rate $(\mathrm{Nc})$ of the resistant pool of $\mathrm{N}$ was higher. The higher decay rate of PMN could be a result of periodic wetting and drying of soils under raised bed planting of crops including wetland rice (Table 5). The influence of the periodic wetting and drying of soils over 
the rice growing season on the decay rate of $\mathrm{N}$ pools under BP resulted in a higher decay rate than even the excessive disturbance of soils under CT. As a result, denitrification, nitrate leaching and ammonia volatilisation and eventually $\mathrm{N}_{2} \mathrm{O}$ emission pathways may result in greater $\mathrm{N}$ loss under BP and CT (Cameron et al., 2013).

Nitrogen management under continuous long term CA may need different rates and timing of $\mathrm{N}$ fertiliser application than the conventional system. Over time, with HR the fertilizer $\mathrm{N}$ requirement for growing crops should decrease by $4 \mathrm{~kg} \mathrm{ha}^{-1}$ (in irrigated rice) to $34 \mathrm{~kg}$ $\mathrm{kg} \mathrm{ha}^{-1}$ (in monsoon rice), equivalent to the extra $\mathrm{N}$ input in residue. In addition, better synchrony between $\mathrm{N}$ supply from soil $\mathrm{N}$ release and $\mathrm{N}$ fertiliser application with crop $\mathrm{N}$ uptake rates may result in lesser losses of $\mathrm{N}$ which further decrease the amounts of fertiliser $\mathrm{N}$ required. However, the sufficiency of $\mathrm{N}$ during early crop growth (0-30 DAS) needs to be confirmed since initial availability was lower under SPHR than CTLR. During the first three years after imposition of SPHR to a wheat-mung bean- monsoon rice rotation at Mymensingh there was no difference in fertiliser $\mathrm{N}$ requirement for maximum yield compared to CTLR (Kader et al., 2016). Based on the present studies, the $\mathrm{N}$ fertiliser requirement over time is likely to decline in the SPHR treatment. However, change in $\mathrm{N}$ fertiliser rates and time of application is also an economic decision. Before adjusting the $\mathrm{N}$ fertiliser rates for $\mathrm{CA}$ it would be necessary to assess response to a range of $\mathrm{N}$ rates and determine the most profitable rates.

The present study has assessed $\mathrm{N}$ availability during the growth of four crops in different seasons on two soil types. However, a gap in the present study is the lack of data on the fallow periods between crops. Loss of available $\mathrm{N}$ may occur during the fallow period before sowing the next crop in the rice intensive triple cropping systems (Rosenani et al., 2003). The transition from oxic to anoxic soil conditions between the early and main monsoon seasons is a period of high risk of denitrification losses of nitrate N (Buresh and De Datta, 1990, 1991; Fadali et al., 2014).

\section{Conclusions}

Increased residue retention together with minimum soil disturbance practices (SP and NP) after 13 crops at Digram (High Barind Tract, Grey Terrace soils) and 14 consecutive crops at Alipur (Level Barind Tract, Calcareous Dark Grey Floodplain soil) increased soil N concentration $(0-10 \mathrm{~cm})$ and either maintained or increased total $\mathrm{N}$ uptake by crops. By contrast, CT with HR produced higher early available mineral $\mathrm{N}$ than SPHR and BPHR treated soils under mustard and rice crops but similar levels to SPHR and BPHR soils under wheat and jute. Bed planting with increased residue retention also slowed $\mathrm{N}$ availability during early crop growth rate and maintained similar N uptake to SP and CT but the soil $\mathrm{N}$ concentration was lower than SPHR. While PMN was higher and its decay rate was lowest with SPHR, crop $\mathrm{N}$ uptake was either similar or enhanced relative to CTLR. We conclude that in the rice based wetland-upland triple cropping systems in the EGP, increased retention of crop residues and minimum soil disturbance (i.e. CA) sequester more soil $\mathrm{N}(0-10 \mathrm{~cm})$ while improving the efficiency of available $\mathrm{N}$ uptake due to better synchrony between availability of soil $\mathrm{N}$ and crop demand.

Findings point to the need for more detailed studies on the effect of $\mathrm{CA}$ on rates $\mathrm{N}$ loss via various pathways (denitrification, nitrate leaching, ammonia volatilisation or surface runoff) so that a complete $\mathrm{N}$ budget can be developed for rice-based intensive cropping systems and the negative environmental implications (acidification, eutrophication and changes in biodiversity) of $\mathrm{N}$ losses.

\section{Author statement}

Md. Khairul and R.W.B. thought up and constructed the research framework and performed the model development; Md. Khairul, R.W.B, M.E.H., M.A.I. and M.A.K. collected and analysed the data; Md. Khairul and M.A.K. worked with the model; Md. Khairul wrote the first draft; R.W.B., M.E.H., M.A.I., and M.A.K. revised the paper.

\section{Declaration of Competing Interest}

The authors would like to disclose that there are no conflicts of interest for any personal, institutional and financial relationships, academic competition, or intellectual passion.

\section{Acknowledgements}

The authors are grateful for the use of laboratories at the Soil Science Division of the Bangladesh Agricultural Research Institute and to the farmers at Alipur and Digram for the use of their land. The author is grateful to Dr Ross Brennan, formerly of the Department of Primary Industries and Regional Development, Western Australia, Australia, for his valuable suggestions that improved the manuscript. The authors also thank the Australian Centre for International Agricultural Research (ACIAR) (Project LWR 2010/080) for research support and a John Allwright Fellowship awarded to the senior author.

\section{Appendix A}

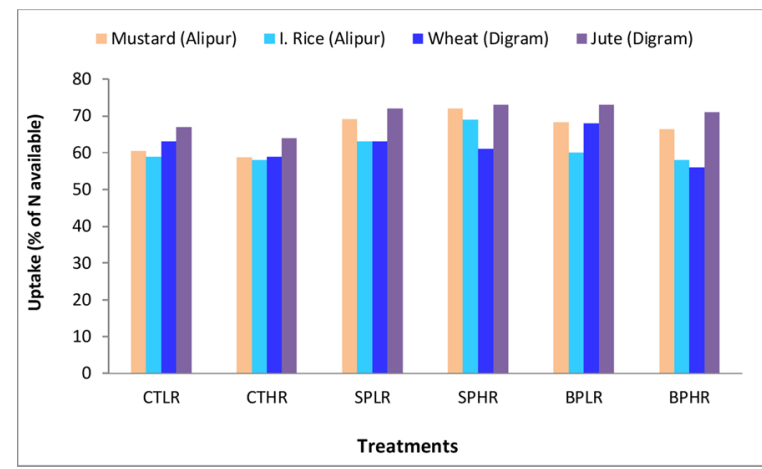

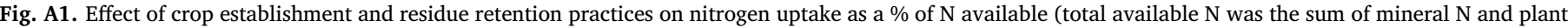

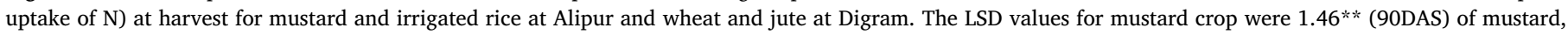

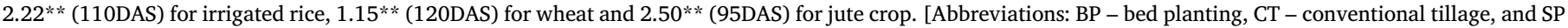

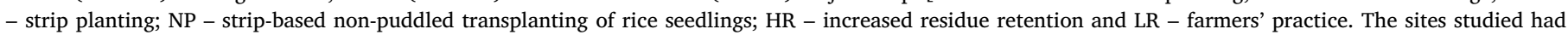

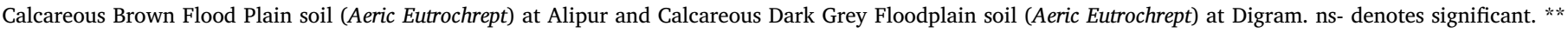
denotes significant at $1 \%$ level of significance. * denotes significant at $5 \%$ level of significance. 


\section{References}

Alam, M.K., Biswas, W.K., Bell, R.W., 2016a. Greenhouse gas implications of novel and conventional rice production technologies in the Eastern-Gangetic plains. J. Clean Prod. 112, 3977-3987.

Alam, M.K., Salahin, N., Islam, S., Begum, R.A., Hasanuzzaman, M., Islam, M.S., Rahman, M.M., 2016b. Patterns of change in soil organic matter, physical properties and crop productivity under tillage practices and cropping systems in Bangladesh. J. Agr. Sci. 155 (2), 216-238.

Alam, M.K., Bell, R.W., Haque, M.E., Kader, M.A., 2018. Minimal soil disturbance and increased residue retention increase soil carbon in rice-based cropping systems on the Eastern Gangetic Plain. Soil Till. Res. 183, 28-41.

Angle, J.S., Gross, C.M., Hill, R.L., Mcintosh, M.S., 1993. Soil nitrate concentrations under corn as affected by tillage, manure and fertilizer application. J. Environ. Qual. 31, $141-147$.

Baldock, J., 2007. Composition and cycling of organic carbon in soil. In: Marschner, P., Rengel, Z. (Eds.), Nutrient Cycling in Terrestrial Ecosystems. Springer, Berlin, Germany, pp. 1-36.

Balota, E.L., Colozzi Filho, A., Andrade, D.S., Dick, R.P., 2004. Long-term tillage and crop rotation effects on microbial biomass and C and N mineralization in a Brazilian Oxisol. Soil Till. Res. 77, 137-145.

Becker, M., Ladha, J.K., Ottow, J.C.G., 1994. Nitrogen losses and lowland rice yield as affected by residue nitrogen release. Soil Sci. Soc. Am. J. 58, 1660-1665.

Bell, R.W., Haque, M.E., Jahiruddin, M., Rahman, M.M., Begum, M., Miah, M.A.M., Islam, M.A., Hossen, M.A., Salahin, N., Zahan, T., Hossain, M.M., Alam, M.K., Mahmud, M.N.H., 2019. Conservation Agriculture for rice-based intensive cropping by smallholders in the Eastern Gangetic Plain. Agriculture 9, 5. https://doi.org/10.3390/ agriculture9010005.

Boateng, S.A., Dennis, E.A., 2000. Management of crop residues for sustainable crop production. J. Ghana Sci. Assoc. 3, 1-243.

Broadbent, F.F., 1984. Plant use of soil nitrogen. In: Haulk, R.D. (Ed.), Nitrogen in Crop Production. ASA, CSSA, and SSSA, Madison, WI, pp. 171-182.

Buresh, R.J., De Datta, S.K., 1990. Denitrification losses from puddled rice soils in the tropics. Biol. Fert. Soils 9, 1-13.

Buresh, R.J., De Datta, S.K., 1991. Nitrogen dynamics and management of rice-legume cropping systems. Adv. Agron. 45, 1-59.

Buresh, R.J., Reddy, K.R., van Kessel, C., 2008. Nitrogen transformations in submerged soils. In: Schepers, J.S., Raun, W.R. (Eds.), Nitrogen in Agricultural Systems. Agronomy Monograph 49. ASA, CSSA, and SSSA, Madison, WI, USA, pp. 401-436.

Busari, M.A., Kukal, S.S., Kaur, A., Bhatt, R., Dulazi, A.A., 2015. Conservation tillage impacts on soil, crop and the environment. ISWCR 3, 119-129.

Cameron, K.C., Di, H.J., Moir, J.L., 2013. Nitrogen losses from the soil/plant system: a review. Ann. Appl. Biol. 162, 145-173.

Cassman, K.G., De Datta, S.K., Olk, D.C., Alcantara, J., S09amson, M., Descalsota, J.P., Dizon, M., 1995. Yield decline and the nitrogen economy of long-term experiments on continuous irrigated rice systems in the tropics. In: Lal, R., Stewart, B.A. (Eds.), Sustainable Management of Soils. Boca Raton, Fla. (USA): Lewis CRC Publishers, pp 181-222.

Chen, B., Liu, E., Tian, Q., Yan, C., Zhang, Y., 2014. Soil nitrogen dynamics and crop residues, a review. Agron. Sustain. Dev. 34, 429-442.

Curtin, D., Francis, G.S., McCallum, F.M., 2008. Decomposition rate of cereal straw as affected by soil placement. Arid. Soil Res. Rehabil. 46, 152-160.

De Neve, S., Pannier, J., Hofman, G., 1996. Temperature effects on C and N mineralization from vegetable crop residues. Plant Soil 181, 25-30.

Dikgwatlhe, S.B., Chen, Z.D., Lal, R., Zhang, H.L., Chen, F., 2014. Changes in soil organic carbon and nitrogen as affected by tillage and residue management under wheat-maize cropping system in the North China Plain. Soil Till. Res. 144, 110-118.

Doran, J.W., Parkin, T.B., et al., 1994. Defining and assessing soil quality. In: Doran, J.W. (Ed.), Defining Soil Quality for a Sustainable Environment. Special Publication No. 35. Soil Science Society of America, Madison, WI, pp. 3-21 1994.

Fadali, O.A., Nassar, M.M., Ibrahim, I.E., Ashour, I.A., Shehata, N., 2014. Effect of lagphase in the transition from oxic to anoxic conditions on the performance of the sequencing batch reactor. IJIAS 7, 393-400.

Franzluebbers, A.J., Hons, F.M., Zuberer, D.A., 1994. Seasonal changes in soil microbial biomass and mineralizable $\mathrm{C}$ and $\mathrm{N}$ in wheat management systems. Soil Biol. Biochem. 26, 1469-1475.

Gathala, M.K., Timsina, J., Islam, S., Rahman, M., Hossain, I., Harun-ar-Rashid, Ghosh, A.K., Krupnik, T.J., Tiwari, T.P., McDonald, A., 2015. Conservation agriculture based tillage and crop establishment options can maintain farmers' yields and increase profits in South Asia's rice-maize systems: evidence from Bangladesh. Field Crops Res. 172, 85-98.

Ghimire, R., Lamichhane, S., Archarya, B.A., Bista, P., Sainju, U.M., 2017. Tillage, crop residue, and nutrient management effects on soil organic carbon in rice-based cropping systems: a review. J. Integr. Agric. 16, 1-15.

Griffin, T.S., 2008. Nitrogen availability. In: Schepers, J., Raun, W.R. (Eds.), Nitrogen in Agricultural Systems. Agron. Monogr. 49. ASA, CSSA, and SSSA, Madison, WI, pp. 613-646.

Guo, L.J., Zhang, Z.S., Wang, D.D., Li, C.F., Cao, C.G., 2015. Effects of short-term conservation management practices on soil organic carbon fractions and microbial community composition under a rice-wheat rotation system. Biol. Fertil. Soils 51, 65-75.

Han, M., Okamoto, M., Beatty, P.H., 2015. The genetics of nitrogen use efficiency in crop plants. Annu. Rev. Genet. 49, 269-289.

Haque, M.E., Bell, R.W., Islam, M.A., Rahman, M.A., 2016. Minimum tillage unpuddled transplanting: an alternative crop establishment strategy for rice in conservation agriculture cropping systems. Field Crops Res. 185, 31-39.

Huang, D., Zhu, P., Wang, Z., Yu, X., 1998. A study and question on the decomposition rate of organic carbon under upland and submerged soil conditions. Acta Pedologica Sinica 35, 482-491.

Islam, M.A., 2016. Conservation Agriculture: Its Effects on Crop and Soil in Rice-based Cropping Systems in Bangladesh. PhD thesis. School of Veterinary and Life Sciences, Murdoch University, Australia.

Islam, M.A., Bell, R.W., Johansen, C., Jahiruddin, M., Haque, M.E., 2016. Nitrogen cycling enhanced by conservation agriculture in a rice-based cropping system of the Eastern Indo-Gangetic Plain. In: Proceedings of the 2016 International Nitrogen Initiative Conference, "Solutions to Improve Nitrogen Use Efficiency for the World". 4-8 December 2016, Melbourne, Australia.

Jackson, M.L., 1956. Soil Chemical Analysis. Prentice-Hall, Inc. Englewood Cliffs, NJ.

Jin, K., Sleutel, S., De Neve, S., Gabriels, D., Hoffman, G., 2008. Nitrogen and carbon mineralization of surface-applied and incorporated winter wheat and peanut residues. Biol. Fertil. Soils 44, 661-665.

Kader, M.A., Sleutel, S., Begum, S.A., Moslehuddin, A.Z.M., De Neve, S., 2013. Nitrogen mineralization in sub-tropical paddy soils in relation to soil mineralogy, management, pH, carbon, nitrogen and iron contents. Eur. J. Soil Sci. 64, 47-57.

Kader, M.A., Jahiruddin, M., Islam, M.R., Haque, M.E., Hasan, M.S., Karmakar, S., Ali, M.M., Bell, R.W., 2016. Strip planting decreases nitrogen fertilizer requirements while retention of more residue increases them in a rice - wheat - mungbean sequence on a subtropical floodplain soil. In: Paper Presented in Proceedings of the 2016 International Nitrogen Initiative Conference, "Solutions to Improve Nitrogen Use Efficiency for the World". 4-8 December 2016, Melbourne, Australia.

Karim, Z., Rahman, S.M., Ali, M.I., Karim, A.J.M.S., 1988. Soil Bulk Density: A Manual for Determination of Soil Physical Parameters. . Soils and Irrigation Division, BARC, Dhaka, Bangladesh.

Carbon and nitrogen dynamics in flooded soils. In: Kirk, G.J.D., Olk, D.C. (Eds.), Proceedings of the Workshop on Carbon and Nitrogen Dynamics in Flooded Soils, 19-22 April 1999. Los Baños, Philippines. Makati City (Philippines): International Rice Research Institute. pp. 188.

Kumar, K., Goh, K.M., 2003. Nitrogen release from crop residues and organic amendments as affected by biochemical composition. Commun. Soil Sci. Plant Anal. 34, 2441-2460.

Liping, G., Erda, L., 2001. Carbon sink in cropland soils and emission of greenhouse gases from paddy soils: a review of work in China. Chemosphere Global Change Sci. 3, 413-418.

Maskina, M.S., Power, J.F., Doran, J.W., Wilhelm, W.W., 1993. Residual effects of no-till crop residues on corn yield and nitrogen uptake. Soil Sci. Soc. Am. J. 57, 1555-1560.

McGarry, S.J., O’Toole, P., Morgan, M.A., 1987. Effects of soil temperature and moisture content on ammonia volatilization from urea-treated pasture and tillage soils. Irish J. Agr. Food. Res. 26, 173-182.

Mondal, R.I., Begum, F., Aziz, A., Sharif, S.H., 2015. Crop sequences for increasing cropping intensity and productivity. SAARC J. Agri. 13, 135-147.

Moslehuddin, A.Z.M., Hussain, M.S., Saheed, S.M., Egashira, K., 1999. Clay mineral distribution in correspondence with agroecological regions of Bangladesh soils. Clay Sci. 11, 83-94.

Nannipieri, P., Paul, E., 2009. The chemical and functional characterization of soil $\mathrm{N}$ and its biotic components. Soil Biol. Biochem. 41, 2357-2369.

Nasim, M., Shahidullah, S.M., Saha, A., Muttaleb, M.A., Aditya, T.L., Ali, M.A., Kabir, M.S., 2017. Distribution of crops and cropping patterns in Bangladesh. Bangladesh Rice J. 21 (2), 1-55.

Nicolardot, B., Fauvet, G., Cheneby, D., 1994. Carbon and nitrogen cycling through soil microbial biomass at various temperatures. Soil Biol. Biochem. 26, 253-261.

Orchard, V.A., Cook, F.J., 1983. Relationship between soil respiration and soil moisture. Soil Biol. Biochem. 15, 447-453.

Page, A.L., Miller, R.H., Kuny, D.R., 1989. Methods of Soil Analysis. Part 2, 2nd edition. American Society of Agronomy, Soil Science Society of America, Madison, Wis, USA 1989.

Palma, R.M., Saubidet, M.I., Rimolo, M., Utsumi, J., 1998. Nitrogen losses by volatilization in a corn crop with two tillage systems in the Argentine Pampa. Commun.Soil Sci.Plan. 29, 2865-2879.

Pekrun, C., Kaul, H.P., Claupein, W., 2003. Soil tillage for sustainable nutrient management. In: ElTiti, A. (Ed.), Soil Tillage in Agroecosystems. CRC Press, Boca Raton, FL, pp. 83-113.

Raiesi, F., 1998. Impacts of elevated atmospheric $\mathrm{CO}_{2}$ on litter quality, litter decomposability and nitrogen turnover rate of two oak species in a Mediterranean forest ecosystem. Glob. Change Biol. 4, 667-678.

Raiesi, F., 2006. Carbon and N mineralization as affected by soil cultivation and crop residue in a calcareous wetland ecosystem in Central Iran. Agric. Ecosyst. Environ. 112, 13-20.

Randall, G.W., Iragavarapu, T.K., 1995. Impact of long-term tillage systems for continuous corn on nitrate leaching to tile drainage. J. Environ. Qual. 24, 360-366.

Rosenani, A.B., Mubarak, A.R., Zauyah, S., 2003. Recycling of crop residues for sustainable crop production in a maize-groundnut rotation system, in: management of crop residues for sustainable crop production. Joint FAO/IAEA Division of Nuclear Techniques in Food and Agriculture IAEA-TECDOC-1354 3-22.

Sapkota, T.B., Jat, R.K., Singh, R.G., Jat, M.L., Stirling, C.M., Jat, M.K., Bijarniya, D., Kumar, M., Yadvinder-Singh, Saharawat, Y.S., Gupta, R.K., 2017. Soil organic carbon changes after seven years of conservation agriculture in a rice-wheat system of the eastern Indo-Gangetic Plains. Soil Use Manag. 33, 81-89.

Singh, N.P., Singh, R.P., Kumar, R., Vashist, A.K., Khan, F., Varghese, N., 2011. Adoption of resource conservation technologies in indo-gangetic plains of India: scouting for 
profitability and efficiency. Agric. Econ. Res. Rev. 24, 15-24.

Sisti, C.P.J., Santos, H.P., Kohhann, R., Alves, B.J.R., Urquiaga, S., Boddey, R.M., 2004 Change in carbon and nitrogen stocks in soil under 13 years of conventional and zero tillage in southern Brazil. Soil Till. Res. 76, 39-58.

Smith, P., Goulding, K.W., Smith, K.A., Powlson, D.S., Smith, J.U., Falloon, P.D., Coleman, K., 2001. Enhancing the carbon sink in European agricultural soils: including trace gas fluxes in estimates of carbon mitigation potential. Nutr. Cycl. Agroecosys. 60, 237-252.

Soon, Y.K., Lupwayi, N.Z., 2012. Straw management in a cold semi-arid region: impact on soil quality and crop productivity. Field Crop Res. 139, 39-46.

SRDI, 2005. Bhumi and Mrittika Sampad Bhavohar Nirdeshika. Gazipur Sadar Upazila, Rajshahi Zila: Bangladesh: Soil Resource Development Institute. Ministry of Agriculture, Government of the People's Republic of Bangladesh (in Bangla).

Stanford, G., Smith, S.J., 1972. Nitrogen mineralisation potentials of soils. Soil Sci. Soc. Am. J. 36, 465-472.

Taneja, G., Deb, P.B., Kumar, J.P., Aggarwal, P.K., Tyagi, N.K., 2014. Farmers Preferences for Climate-smart Agriculture: an Assessment in the Indo-Gangetic Plain. International Food Policy Research Institute, pp. 2.

Timsina, J., Panaullah, G.M., Saleque, M.A., Ishaque, M., Pathan, A.B.M.B.U., Quayyum, M.A., Connor, D.J., Saha, P.K., Humphreys, E., Meisner, C.A., 2006. Nutrient uptake and apparent balances for rice-wheat sequences: I. Nitrogen. J. Plant Nutr. 29, 137-156.

Van Kessel, J.S., Reeves III, J.B., Meisinger, J.J., 2000. Nitrogen and carbon mineralization potential of manure components. J. Environ. Qual. 29, 1669-1677.

Verhulst, N., François, I., Grahmann, K., Cox, R., Govaerts, B., 2013. Nitrogen use efficiency and optimization of nitrogen fertilization in conservation agriculture. $C A B$ Rev. 8, 1-19.

Wang, Y., Hsieh, Y.P., 2002. Uncertainties and novel prospects in the study of the soil carbon dynamics. Chemosphere 49, 791-804.

Watkins, N., Barraclough, D., 1996. Gross rates of $\mathrm{N}$ mineralization associated with the decomposition of plant residues. Soil Biol. Biochem. 28, 169-175.

Wienhold, B.J., Halvorson, A.D., 1999. Nitrogen mineralization responses to cropping, tillage, and nitrogen rate in the northern Great Plains. Soil Sci. Soc. Am. J. 63, 192-196.

Witt, C., Cassman, K.G., Olk, D.C., Biker, U., Liboon, S.P., Samson, M.I., Ottow, J.C.G. 2000. Crop rotation and residue management effects on carbon sequestration, nitrogen cycling, and productivity of irrigated rice systems. Plant Soil 225, 263-278.

Wright, A.L., Reddy, K.R., 2001. Heterotrophic microbial activity in Northern Everglades wetland soils. Soil Sci. Soc. Am. J. 65, 1856-1864.

Xu, G.H., Fan, X.R., Miller, A.J., 2012. Plant nitrogen assimilation and use efficiency. Ann. Rev. Plant Biol. 63, 153-182.

Xue, J.F., Pu, C., Liu, S.L., Chen, Z.D., Chen, F., Xiao, X.P., Lal, R., Zhang, H.L., 2015. Effects of tillage systems on soil organic carbon and total nitrogen in a double paddy cropping system in Southern China. Soil Till. Res. 153, 161-168.

Yadav, G.S., Lal, R., Meena, R.S., Babu, S., Das, A., Bhowmik, S.N., Datta, M., Layak, J., Saha, P., 2017. Conservation tillage and nutrient management effects on productivity and soil carbon sequestration under double cropping of rice in north eastern region of India. Ecol. Indic. 105, 303-315.

Zhou, W., Lv, T., Chen, Y., Westby, A.P., Ren, W., 2014. Soil physicochemical and biological properties of paddy-upland rotation: a review. SWJ 2014, 856352. 